\title{
20. VOLCANIC GLASS IN ABYSSAL CLAYS SAMPLED AT DSDP LEG 20 DRILLING SITES, NORTHWEST PACIFIC
}

\author{
E. John W. Jones, Department of Geology, University College London
}

\section{INTRODUCTION}

Volcanic glass is an important component of many parts of the silty clay sequences recovered on Leg 20 of the Deep Sea Drilling Project (Figure 1). The proportion of vitric material varies widely, from almost $100 \%$ in ash layers to trace amounts (less than 2\%) dispersed in some of the abyssal brown clays. Photomicrographs of a selection of smear slides containing glass shards and splinters are presented in Plate 1.

The occurrence of volcanic glass in deep-sea clays in the western Pacific has, of course, been known for a long time (Murray and Renard, 1891). Piston cores taken within an extensive zone, some $1000-1300 \mathrm{~km}$ wide, on the oceanward side of the Japan and Kurile arcs generally contain at least one layer of vitric ash (Ninkovich et al., 1966; Horn et al., 1969; 1970). A few studies of the glass in core samples have been made, such as those of Ninkovich et al. (1966), but they have necessarily been restricted to relatively young (Pliocene-Recent) accumulations. The cores recovered on Leg 20 have now provided an opportunity of examining volcanic glass deposited at much earlier periods on the western edge of the Pacific plate. This report presents analyses of glass shards from sediments as old as Campanian, based upon refractive index and electron microprobe studies. The principal objective of this preliminary investigation has been to define, insofar as the limited number of cores allows, the major compositional variations of the vitric fraction of sediments laid down during the late Mesozoic and Tertiary.

\section{PREPARATION OF SAMPLES AND METHODS OF ANALYSIS}

Twelve core samples were chosen to provide a representative selection of glass from the clays recovered at the northern drill sites (Sites 194 to 198; Figure 1; Table 1). In addition, one sample (VIII; Table 1) from Site 199 at the edge of the Caroline Abyssal Plain was examined.

In order to concentrate the glass shards, about $3 \mathrm{cc}$ of the sediment was boiled in hydrogen peroxide. The residue was washed and then filtered through a $62.5 \mu$ sieve, the process being repeated until the clay-sized fraction was eliminated.

The variation of refractive index of the glass within each sample was determined by comparing roughly 200 grains with a series of liquids whose indexes were measured with an Abbé refractometer in sodium light. The spread in values is shown by a series of histograms in Figure 2. Most of the samples are unimodal, some distributions being sharply peaked (Samples I and VI). It was on the basis of compositional variations revealed by refractive index that shards were selected for analysis with the microprobe in order to study differences in composition within a single sample and between samples of different ages and locations.

The glass shards were separated by hand and mounted in epoxy resin for polishing. Plate 2 shows an example of the result of the mounting and polishing procedures. Small quartz, feldspar, and other grains inevitably contaminated the sample, but these could generally be identified by examining the polished mount in transmitted light. About 10 glass grains were selected, and three analyses were made on each for nine major elements. The results for each grain were averaged and the microprobe correction applied using a computer program written by Mason et al. (1969).

\section{COMPOSITIONAL VARIATIONS}

Based upon the refractive index of the vitric component the samples fall into two quite distinct groups: those containing glass, usually colorless, whose values fall below 1.56; and those with glass shards, usually yellow or brown in color, the refractive indexes of which are generally higher than this figure (Figure 2). If we disregard the sample from Site 199 (Sample VIII), which is well south of the other drilling locations and also contains reworked material according to paleontological examinations by $\mathrm{H}$. Hekel and V. Krasheninnikov, it can be seen that the low refractive index (R.I.) glass is confined to the Tertiary and Quaternary clays. Quaternary Sample I from Site 194 and upper Miocene Sample VI have sharply peaked histograms indicating a relatively narrow range of compositions. The glass with high refractive index is found in significant quantities only in the Cretaceous sediments of the northern drilling sites. In these clays the refractive index of over $80 \%$ of shards falls between 1.57 and 1.60 .

Some of the compositional variations have been investigated with the electron microprobe. Tables 2 to 7 summarize the analyses of each of the shards so far examined. As expected from earlier work on the relationship between refractive index and silica content (Tilley, 1922; Williams et al., 1954; Ross and Smith, 1955), the high refractive index shards of Sample VIII are mainly of basic composition (Figure 3, Table 7). Microprobe analyses have not yet been carried out on the Cretaceous samples (IX-XIII), but the range of refractive indexes is similar to that of Sample VIII (Figure 2), indicating a preponderance of glass of basic composition. The presence of basic glass in Cretaceous sediments is unexpected because shards of this composition are usually assumed to be particularly susceptible to diagenetic alteration. Some alteration is seen (Plate 1[6]), but it is usually quite minor. According to measured hydration rates of glassy margins of submarine basalts $\left(480-200 \mu^{2} / 1000\right.$ years; Moore, 1970) silt-sized basic glass shards should not occur in late Mesozoic sediments, yet they are present in significant amounts in the Campanian 


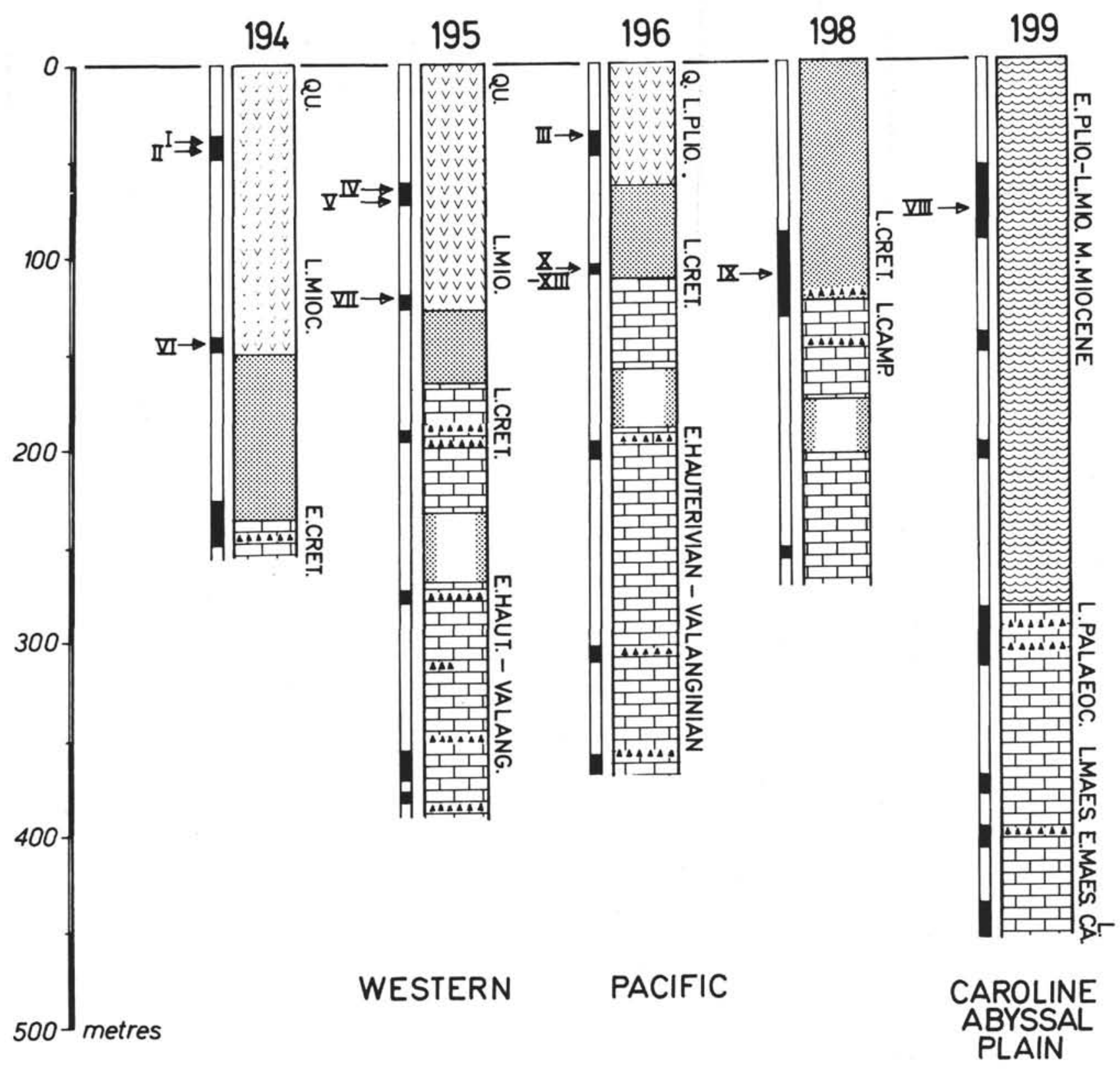

LEGEND

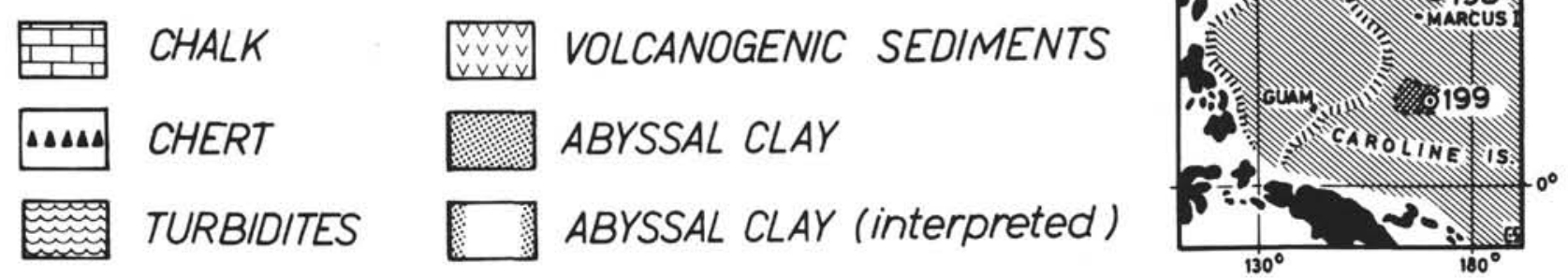

Figure 1. Stratigraphy at the DSDP Leg 20 drilling sites discussed in text. Locations of clay samples from which glass was extracted for analysis are indicated by Roman numerals (see Table 1 also). The cored intervals are indicated in black. 
TABLE 1

Sample Data

\begin{tabular}{llccccl}
\hline & \multicolumn{2}{c}{ Sample } & North & East & Water Depth Subbottom & \\
& & & & Septh $(\mathrm{m})$ & Age \\
\hline (I) & $194-1-1,114-115$ & $33^{\circ} 58.68^{\prime}$ & $146^{\circ} 48.64^{\prime}$ & 5754 & 38.6 & Quaternary \\
(II) & $194-1-3,57-59$ & $33^{\circ} 58.68^{\prime}$ & $146^{\circ} 48.64^{\prime}$ & 5754 & 41.1 & Quaternary \\
(III) & $196-1-1,132-133$ & $30^{\circ} 06.97^{\prime}$ & $148^{\circ} 34.49^{\prime}$ & 6194 & 38.8 & Quaternary \\
(IV) $195-1-3,64-66$ & $32^{\circ} 46.40^{\prime}$ & $146^{\circ} 58.73^{\prime}$ & 5968 & 66.7 & Plio/Pleistocene \\
(V) $195-1-5,50-52$ & $32^{\circ} 46.40^{\prime}$ & $146^{\circ} 58.73^{\prime}$ & 5968 & 69.5 & Plio/Pleistocene \\
(VI) $194-2-1,145-147$ & $33^{\circ} 58.68^{\prime}$ & $146^{\circ} 48.64^{\prime}$ & 5754 & 143.4 & Upper Miocene \\
(VII) $195-2-2,141-143$ & $32^{\circ} 46.40^{\prime}$ & $146^{\circ} 58.73^{\prime}$ & 5968 & 122.9 & Middle Miocene \\
(VIII) $199-3-1,146-148$ & $13^{\circ} 30.78^{\prime}$ & $156^{\circ} 10.34^{\prime}$ & 6100 & 78.0 & Middle Miocene \\
(IX) $198 \mathrm{~A}-3-1,64-66$ & $25^{\circ} 49.54^{\prime}$ & $154^{\circ} 35.05^{\prime}$ & 5958 & 110.2 & Late Cretaceous \\
(X) $196-2-2,51-53$ & $30^{\circ} 06.97^{\prime}$ & $148^{\circ} 34.49^{\prime}$ & 6194 & 106.0 & Campanian \\
(XI) $196-2-2,62-63$ & $30^{\circ} 06.97^{\prime}$ & $148^{\circ} 34.49^{\prime}$ & 6194 & 106.1 & Campanian \\
(XII) $196-2-4,57-59$ & $30^{\circ} 06.97^{\prime}$ & $148^{\circ} 34.49^{\prime}$ & 6194 & 109.1 & Campanian \\
(XIII) $196-2-4,119-120$ & $30^{\circ} 06.97^{\prime}$ & $148^{\circ} 34.49^{\prime}$ & 6194 & 109.7 & Campanian \\
\hline
\end{tabular}

aWith reworked Early Tertiary components.

(75 m.y.) clays of Hole 196. It is interesting to note that basaltic glass showing only minor alteration has been found in even older sediments. Brew and Muffler (1965) and Muffler et al. (1969), for example, have described studies made on relatively fresh basaltic glass extracted from tuffs of Upper Triassic age in southeast Alaska. It is not yet clear which of many possible factors, such as the low temperature within the abyssal clays of the $\mathrm{pH}$ of the interstitial waters, is responsible for their survival. However, as it appears that the basic component of the vitric fraction is not preferentially removed during diagenesis, the glass in the clays may be used to infer the volcanic history of the source areas.

The low refractive index glasses are products of extreme differentiation, with silica contents often exceeding $75 \%$ (Tables 2-6). The expression

$$
\text { R.I. }=1.693-\left(0.00226 \times \% \mathrm{SiO}_{2}\right)
$$

can be used as a rough guide to compositional variation (Figure 3). It is not an exact relationship, since other components besides $\mathrm{SiO}_{2}$ (such as water) are known to have a pronounced influence on refractive index (Ross and Smith, 1955), and they have not been estimated at this stage of the investigation. It is significant that samples lying farthest from the least-squares line in Figure 3 have the highest residuals in the microprobe analyses $(100 \%$ which is the total of elements investigated); this may express a high volatile content.

The results of the analyses of the glass shards are displayed on AFM diagrams in Figures 4 and 5 and on variation diagrams in Figures 6 to 9 . It can be seen that a range of compositions is represented, the greatest variation being found in Sample VIII from Site 199. $\mathrm{CaO}$ and $\mathrm{FeO}$ fall rapidly with increasing silica content, while the decrease of $\mathrm{MnO}$ and $\mathrm{MgO}$ is more gradual. These compositional differences reflect stages in the differentiation of parental magmas in the source areas. The Neogene samples from the northern drilling sites clearly fall towards the acidic end of a differentiation trend (Figure 5), and the overlapping of the Miocene-Recent fields suggests that the volcanoes from which the glass originated may be closely associated in their development. On the AFM and major element variation diagrams, the glass from Site 199 is quite distinct from the Neogene glass recovered at the northern sites, implying two quite separate source areas.

A preliminary examination of Quaternary acidic and Cretaceous basic glass has been made using a scanning electron microscope (Samples I, XI, and XIII; Plates 3-9) in order to compare their morphology. Some important differences in the internal structures and surface textures are revealed.

The most obvious point of contrast lies in the striking vesicularity of the Quaternary acidic material and the almost complete absence of vesicles in the Campanian glass. In many of the acid shards the vesicles are pipe-shaped (Plate 4), the diameters of the pipes usually lying between 1 and $20 \mu$. The overall shape of the shard is controlled by the direction of the pipe vesicles (Plates 3, 4, and 5), a feature which has been observed in vitric ash from Katmai by Heiken (1972). In some shards the vesicles are pod-shaped (Plate 2[3]). Scalloped surfaces are also quite common. Plate 6 shows an arrowhead-shaped shard which appears to have been part of the wall of three pod-shaped vesicles. The pipe- and pod-shaped vesicles were evidently formed at a relatively late stage by the elongation of roughly spherical cavities through the flow of extremely viscous acidic magma at a high level in the parental volcano.

The glass extracted from the Campanian clays, on the other hand, is very rarely vesicular. Droplet-shaped shards indicative of quenching of a relatively fluid magma are common (Plates 8 and 9). Other shards are markedly angular with smooth surfaces and show striking examples of conchoidal fracturing (Plate 7). Some percussion structures formed during comminution mimic those seen at a very much larger scale when basaltic glass is shattered with a hammer. Concentric and radial percussion marks are well displayed on Plate 7.

\section{SOURCE AREAS}

The analyses have shown that the glass in the NeogeneRecent sediments recovered at the northern drilling sites is of quite different composition from that found in the 
E. J.W. JONES

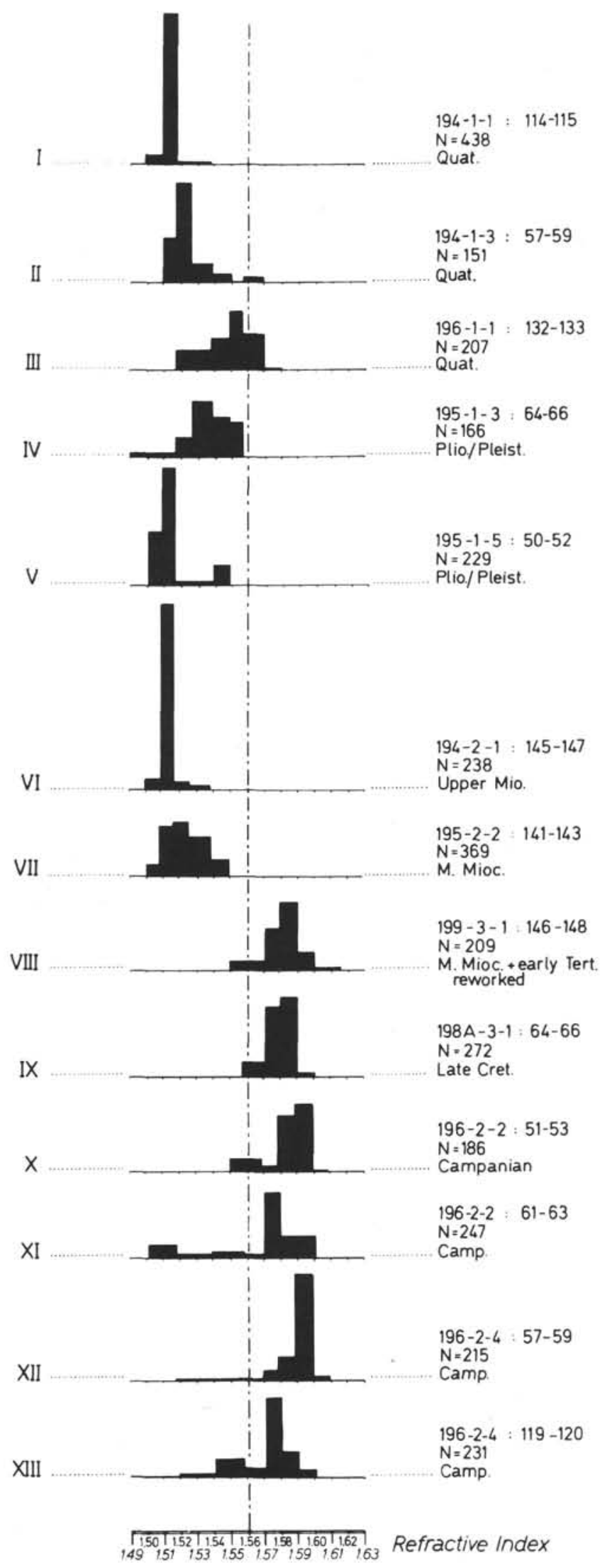

Figure 2. Refractive index of glass particles in clays from Positions I to XIII in Figure 1. N is the number of glass grains examined in each sample. Each histogram is plotted on the same scale. The samples are annotated according to the usual DSDP convention (i.e., 196-2-4, 119-120 was taken from between 119 and $120 \mathrm{~cm}$ below the top of the fourth section of Core 2 at Site 196). 
TABLE 2

Compositions of 10 Glass Grains from Sample I

(194-1-1, 114-115; Quaternary)

\begin{tabular}{|c|c|c|c|c|c|c|c|c|c|c|c|}
\hline \multicolumn{11}{|c|}{ Grain } & \multirow[b]{2}{*}{ Average } \\
\hline & 1 & 2 & 3 & 4 & 5 & 6 & 7 & 8 & 9 & 10 & \\
\hline $\mathrm{SiO}_{2}$ & 78.2 & 80.4 & 80.1 & 64.4 & 80.5 & 82.4 & 80.1 & 75.1 & 81.0 & 81.6 & 79.9 \\
\hline $\mathrm{CaO}^{2}$ & 0.5 & 0.7 & 0.5 & 7.7 & 0.5 & 0.6 & 0.7 & 0.7 & 0.5 & 0.4 & 0.6 \\
\hline $\mathrm{Al}_{2} \mathrm{O}_{3}$ & 10.7 & 10.5 & 10.0 & 19.7 & 9.7 & 10.4 & 10.4 & 9.3 & 9.2 & 9.8 & 10.0 \\
\hline $\mathrm{TiO}_{2}$ & - & 0.1 & 0.3 & 0.05 & 0.2 & 0.1 & 0.2 & 0.1 & 0.03 & 0.2 & 0.1 \\
\hline $\mathrm{MgO}$ & 0.3 & - & - & - & 0.1 & 0.1 & 0.3 & - & - & - & 0.1 \\
\hline $\mathrm{FeO}$ & 0.7 & 0.04 & 0.8 & 1.1 & 0.7 & 0.6 & 0.6 & 0.7 & 0.7 & 0.7 & 0.7 \\
\hline $\mathrm{MnO}$ & 0.03 & 0.04 & 0.04 & - & 0.1 & 0.1 & 0.1 & 0.04 & 0.1 & 0.1 & 0.07 \\
\hline $\mathrm{K}_{2} \mathrm{O}$ & 2.7 & 2.4 & 2.1 & 0.1 & 2.0 & 2.4 & 2.2 & 1.9 & 2.5 & 2.5 & 2.3 \\
\hline Total & 93.1 & 94.3 & 93.8 & 93.1 & 93.9 & 96.8 & 94.6 & 87.8 & 94.0 & 95.3 & 93.8 \\
\hline
\end{tabular}

TABLE 3

Compositions of 14 Glass Grains from Sample IV (195-1-3, 64-66; Plio/Pleistocene)

\begin{tabular}{|c|c|c|c|c|c|c|c|c|c|c|c|c|c|c|c|}
\hline & \multicolumn{14}{|c|}{ Grain } & \multirow[b]{2}{*}{ Average } \\
\hline & 1 & 2 & 3 & 4 & 5 & 6 & 7 & 8 & 9 & 10 & 11 & 12 & 13 & 14 & \\
\hline $\mathrm{SiO}_{2}$ & 79.2 & 66.2 & 63.3 & 65.4 & 65.0 & 73.8 & 76.5 & 68.7 & 72.4 & 82.3 & 64.0 & 68.4 & 71.6 & 69.3 & 70.4 \\
\hline $\mathrm{CaO}^{2}$ & 2.3 & 7.8 & 6.4 & 7.4 & 8.7 & 5.7 & 4.1 & 6.1 & 5.3 & 3.0 & 7.9 & 6.3 & 5.5 & 5.4 & 5.9 \\
\hline $\mathrm{Al}_{2} \mathrm{O}_{3}$ & 11.2 & 12.8 & 12.4 & 13.4 & 16.3 & 11.9 & 11.9 & 12.0 & 13.4 & 10.6 & 12.8 & 14.3 & 12.3 & 13.3 & 12.8 \\
\hline $\mathrm{TiO}_{2}$ & 0.3 & 0.6 & 1.0 & 0.6 & 0.8 & 0.7 & 0.8 & 0.5 & 0.6 & 0.4 & 0.9 & 0.7 & 0.9 & 0.6 & 0.7 \\
\hline $\mathrm{MgO}^{2}$ & 0.2 & 2.0 & 1.8 & 3.2 & 1.5 & 1.5 & 1.2 & 1.3 & 0.8 & 0.3 & 2.1 & 0.9 & 1.3 & 1.4 & 1.4 \\
\hline $\mathrm{FeO}$ & 2.7 & 8.2 & 8.8 & 9.5 & 9.3 & 6.9 & 4.6 & 7.4 & 6.5 & 2.8 & 8.7 & 7.2 & 8.0 & 8.1 & 7.1 \\
\hline $\mathrm{MnO}$ & 0.1 & 0.3 & 0.3 & 0.2 & 0.3 & 0.2 & 0.1 & 0.2 & 0.2 & 0.1 & 0.2 & 0.2 & 0.2 & 0.2 & 0.2 \\
\hline $\mathrm{K}_{2} \mathrm{O}$ & 1.0 & 0.3 & 0.2 & 0.4 & 0.2 & 0.5 & 0.3 & 0.3 & 0.4 & 0.4 & 0.3 & 0.3 & 0.4 & 0.2 & 0.4 \\
\hline $\mathrm{Na}_{2} \mathrm{O}$ & 0.7 & 0.8 & 0.3 & 1.1 & 2.8 & 0.8 & - & 0.5 & 0.3 & - & 0.4 & 1.0 & 0.4 & 1.5 & 0.8 \\
\hline Total & 97.8 & 99.0 & 94.4 & 101.1 & 104.9 & 101.9 & 99.3 & 96.9 & 99.8 & 99.8 & 97.2 & 99.3 & 100.6 & 100.1 & 99.7 \\
\hline
\end{tabular}

TABLE 4

Compositions of 9 Glass Grains from Sample V

(195-1-5; 50-52; Plio/Pleistocene)

\begin{tabular}{|c|c|c|c|c|c|c|c|c|c|c|}
\hline \multicolumn{10}{|c|}{ Grain } & \multirow[b]{2}{*}{ Average } \\
\hline & 1 & 2 & 3 & 4 & 5 & 6 & 7 & 8 & 9 & \\
\hline $\mathrm{SiO}_{2}$ & 78.6 & 83.6 & 82.9 & 81.9 & 85.2 & 80.6 & 82.5 & 78.2 & 79.5 & 81.4 \\
\hline $\mathrm{CaO}^{2}$ & 1.4 & 1.5 & 1.7 & 1.6 & 1.6 & 1.5 & 1.1 & 1.7 & 1.8 & 1.5 \\
\hline $\mathrm{A}{ }_{2} \mathrm{O}_{3}$ & 11.2 & 12.6 & 11.3 & 11.1 & 10.5 & 11.2 & 12.3 & 10.7 & 10.4 & 11.3 \\
\hline $\mathrm{TiO}_{2}$ & 0.3 & 0.2 & 0.2 & 0.1 & 0.2 & 0.1 & 0.3 & 0.2 & 0.1 & 0.2 \\
\hline $\mathrm{MgO}$ & - & 0.1 & 0.1 & 0.1 & 0.2 & 0.1 & 0.2 & 0.2 & 0.4 & 0.2 \\
\hline $\mathrm{FeO}$ & 1.3 & 1.1 & 1.3 & 1.3 & 1.4 & 1.1 & 1.3 & 1.2 & 1.2 & 1.2 \\
\hline $\mathrm{MnO}$ & 0.1 & 0.04 & 0.1 & 0.1 & 0.05 & 0.04 & 0.08 & 0.07 & 0.1 & 0.08 \\
\hline $\mathrm{K}_{2} \mathrm{O}$ & 0.9 & 0.9 & 0.9 & 1.1 & 1.0 & 0.8 & 1.2 & 1.1 & 1.0 & 1.0 \\
\hline $\mathrm{Na}_{2} \mathrm{O}$ & 0.08 & 2.3 & 0.08 & 0.4 & 0.08 & 0.4 & 1.5 & 0.09 & 1.1 & 0.7 \\
\hline Total & 93.9 & 102.2 & 98.6 & 97.8 & 100.2 & 96.0 & 100.3 & 93.4 & 95.6 & 97.6 \\
\hline
\end{tabular}


TABLE 5

Compositions of 14 Glass Grains from Sample VI (194-2-1, 145-147; Upper Miocene)

\begin{tabular}{|c|c|c|c|c|c|c|c|c|c|c|c|c|c|c|c|}
\hline & \multicolumn{14}{|c|}{ Grain } & \multirow[b]{2}{*}{ Averag } \\
\hline & 1 & 2 & 3 & 4 & 5 & 6 & 7 & 8 & 9 & 10 & 11 & 12 & 13 & 14 & \\
\hline $\mathrm{SiO}_{2}$ & 72.6 & 72.9 & 78.3 & 78.3 & 73.5 & 78.0 & 69.2 & 78.3 & 82.6 & 74.1 & 74.4 & 71.8 & 70.0 & 75.9 & 75.0 \\
\hline $\mathrm{CaO}^{2}$ & 0.6 & 1.0 & 0.6 & 0.8 & 0.6 & 0.6 & 0.9 & 1.0 & 0.5 & 0.7 & 0.6 & 1.0 & 0.9 & 0.7 & 0.8 \\
\hline $\mathrm{Al}_{2} \mathrm{O}_{3}$ & 10.4 & 11.0 & 12.5 & 10.3 & 10.8 & 11.0 & 11.1 & 10.4 & 11.9 & 10.9 & 12.6 & 11.6 & 11.8 & 12.4 & 11.3 \\
\hline $\mathrm{TiO}_{2}$ & 0.1 & 0.4 & 0.2 & - & - & 0.04 & - & 0.1 & 0.1 & - & 0.1 & 0.08 & - & - & 0.1 \\
\hline $\mathrm{MgO}$ & - & - & - & - & 0.1 & - & - & 0.3 & - & - & - & - & - & - & 0.03 \\
\hline $\mathrm{FeO}$ & 0.6 & 1.0 & 0.5 & 0.6 & 0.5 & 0.8 & 0.8 & 0.9 & 0.6 & 0.7 & 0.8 & 1.0 & 0.6 & 0.7 & 0.7 \\
\hline $\mathrm{MnO}$ & 0.06 & - & 0.03 & 0.06 & 0.03 & 0.05 & 0.1 & - & 0.02 & 0.02 & 0.04 & 0.04 & 0.08 & 0.02 & 0.04 \\
\hline $\mathrm{K}_{2} \mathrm{O}$ & 3.6 & 2.6 & 3.3 & 3.0 & 3.1 & 2.2 & 3.9 & 2.9 & 3.1 & 3.6 & 2.1 & 1.5 & 3.5 & 2.3 & 2.9 \\
\hline $\mathrm{Na}_{2} \mathrm{O}$ & 0.1 & - & 1.6 & 0.7 & 1.6 & 1.2 & 0.7 & 0.1 & 1.6 & 0.4 & 1.4 & 0.3 & 1.3 & 0.9 & 0.9 \\
\hline Total & 88.2 & 88.8 & 96.9 & 93.7 & 90.3 & 93.8 & 86.7 & 94.1 & 100.4 & 90.3 & 92.1 & 87.2 & 88.0 & 92.9 & 91.7 \\
\hline
\end{tabular}

TABLE 6

Compositions of 11 Glass Grains from Sample VII (195-2-2, 141-143; Middle Miocene)

\begin{tabular}{lcccccccccccc}
\hline & \multicolumn{10}{c}{ Grain } & \\
\cline { 2 - 10 } & 1 & 2 & 3 & 4 & 5 & 6 & 7 & 8 & 9 & 10 & 11 & Average \\
\hline $\mathrm{SiO}_{2}$ & 78.1 & 76.9 & 74.3 & 83.9 & 80.4 & 85.1 & 77.4 & 78.6 & 91.3 & 72.3 & 73.8 & 79.3 \\
$\mathrm{CaO}$ & 1.7 & 1.7 & 1.9 & 1.1 & 0.7 & 1.4 & 2.1 & 1.3 & 1.8 & 2.1 & 0.9 & 1.5 \\
$\mathrm{Al}_{2} \mathrm{O}_{3}$ & 9.4 & 13.7 & 11.6 & 11.5 & 9.9 & 13.7 & 10.2 & 9.7 & 10.1 & 8.9 & $10.7(9)$ & 10.9 \\
$\mathrm{TiO}_{2}$ & 0.2 & 0.1 & 0.1 & - & 0.2 & 0.2 & 0.4 & 0.2 & 0.1 & 0.2 & 0.1 & 0.2 \\
$\mathrm{MgO}$ & 0.3 & 0.1 & 0.04 & 0.1 & - & 0.4 & 0.4 & - & 0.3 & 0.2 & 0.09 & 0.2 \\
$\mathrm{FeO}$ & 1.6 & 1.4 & 1.9 & 1.4 & 1.4 & 1.9 & 2.0 & 1.7 & 2.1 & 1.5 & 1.5 & 1.7 \\
$\mathrm{MnO}$ & - & 0.05 & 0.06 & - & 0.08 & 0.03 & 0.08 & 0.1 & 0.05 & 0.06 & 0.09 & 0.05 \\
$\mathrm{~K}_{2} \mathrm{O}$ & 0.8 & 1.1 & 0.6 & 1.0 & 1.2 & 0.3 & 1.1 & 0.7 & 0.7 & 1.5 & 0.8 & 0.9 \\
$\mathrm{Na}_{2} \mathrm{O}$ & 0.6 & - & 0.8 & - & - & 0.2 & - & 0.8 & - & 0.9 & - & 0.3 \\
Total & 92.8 & 95.2 & 91.3 & 99.9 & 94.0 & 103.2 & 93.4 & 93.1 & 106.6 & 87.6 & 87.9 & 95.1 \\
\hline
\end{tabular}

TABLE 7

Compositions of 11 Glass Grains from Sample VIII (199-3-1; 146-148; Middle Miocene with Reworked Early Tertiary)

\begin{tabular}{lcccccccccccc}
\hline & \multicolumn{10}{c}{ Grain } & \\
\cline { 2 - 11 } & 1 & 2 & 3 & 4 & 5 & 6 & 7 & 8 & 9 & 10 & 11 & Average \\
\hline $\mathrm{SiO}_{2}$ & 61.7 & 56.9 & 53.6 & 48.9 & 50.6 & 47.0 & 45.9 & 50.9 & 54.0 & 57.1 & 57.0 & 49.4 \\
$\mathrm{CaO}$ & 6.7 & 11.5 & 7.7 & 20.1 & 10.9 & 18.9 & 20.7 & 11.9 & 11.9 & 8.6 & 11.2 & 12.9 \\
$\mathrm{Al}_{2} \mathrm{O}_{3}$ & 24.8 & 28.4 & 24.8 & 2.6 & 22.3 & 5.3 & 5.4 & 27.6 & 29.2 & 25.6 & 29.1 & 28.0 \\
$\mathrm{TiO}_{2}$ & 0.1 & 0.3 & 0.2 & 1.3 & 0.2 & 2.9 & 3.0 & 0.1 & 0.2 & 0.2 & 0.2 & 0.1 \\
$\mathrm{MgO}$ & 0.07 & 0.02 & 0.07 & 10.5 & 0.1 & 4.7 & 14.6 & 1.2 & 0.6 & 0.09 & 0.3 & $0.79 \mathrm{a}$ \\
$\mathrm{FeO}$ & 0.5 & 0.7 & 0.5 & 9.1 & 0.8 & 8.2 & 8.0 & 3.5 & 3.6 & 0.8 & 0.8 & 1.3 \\
$\mathrm{MnO}$ & - & - & - & 0.2 & 0.05 & 0.09 & 0.2 & 0.03 & 0.08 & - & 0.05 & 0.10 \\
$\mathrm{~K}_{2} \mathrm{O}$ & 0.9 & 0.3 & 0.7 & 0.03 & 0.2 & 0.5 & - & 0.6 & 0.05 & 0.2 & 0.4 & 0.1 \\
$\mathrm{Na}_{2} \mathrm{O}$ & 4.9 & 4.1 & 7.1 & - & 4.9 & 5.1 & - & 4.6 & 3.8 & 4.8 & 5.1 & 4.3 \\
\multicolumn{1}{c}{$\mathrm{Total}$} & 99.7 & 102.3 & 94.7 & 92.7 & 90.1 & 92.7 & 97.8 & 100.4 & 103.5 & 97.3 & 104.1 & 96.0 \\
\hline
\end{tabular}

aExcludes Grains 4 and 7. 


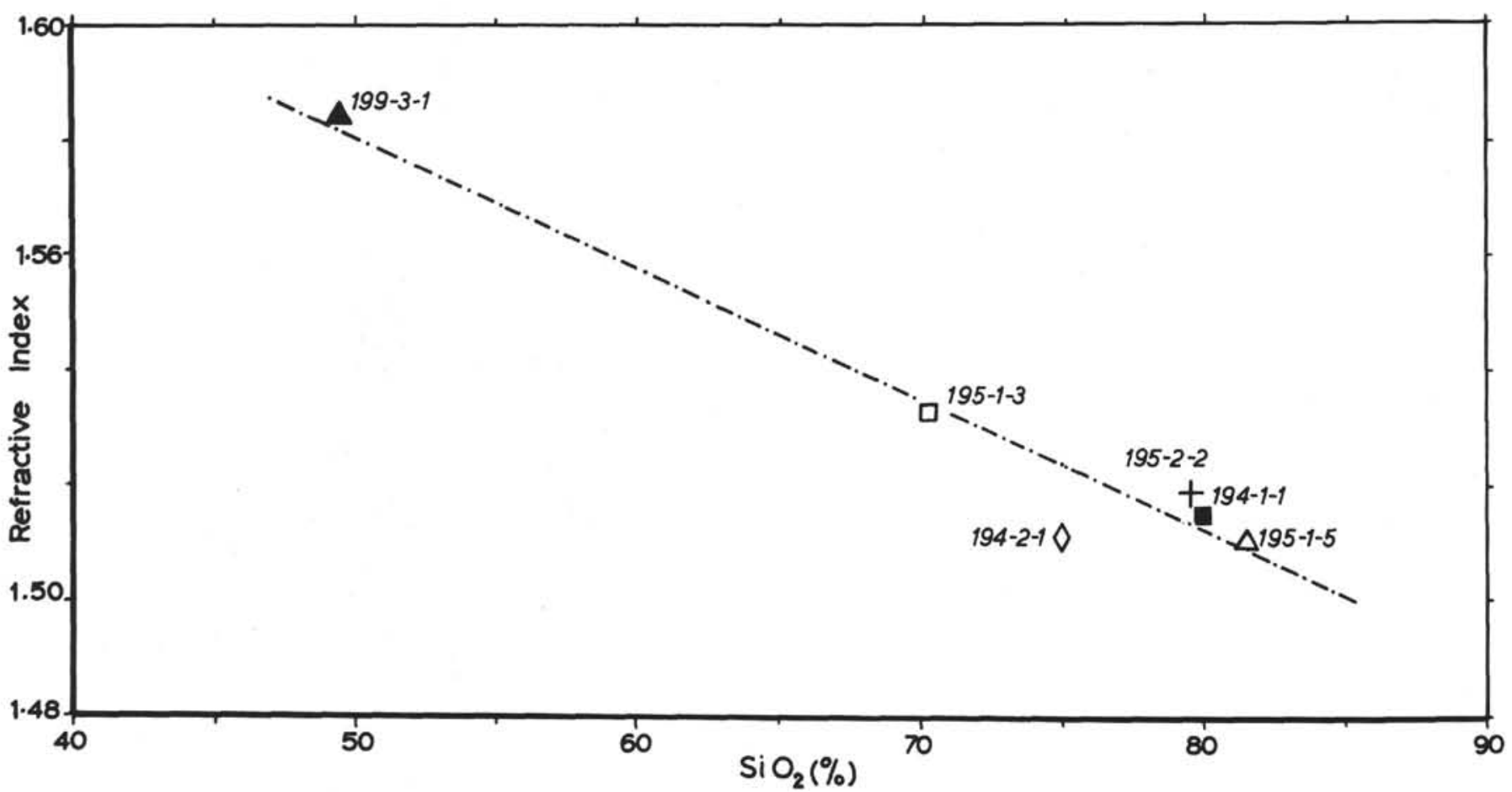

Figure 3. Relationship between refractive index and $\mathrm{SiO}_{2}$ content for six glass samples.

Upper Cretaceous clays, a difference which is also reflected in their morphology. A contrast in composition because of diagenetic changes is precluded by the earlier considerations. Thus, the fine-grained vitric ejecta reaching this part of the Pacific plate evidently changed from a basic to a more acidic character during some period between the Late Cretaceous and early Miocene (Figure 2). The core samples are too few to provide more exact dating (Figure 1). This significant shift in composition could mirror a change in the character of volcanism in the source areas, a change of source area, or both. The abundance of glass of acidic and intermediate types and the lack of a large basic component are strong reasons for believing that the glass in the Neogene-Recent clays originated in the island arc region to the west. Furthermore, the glass generally has a low $\mathrm{TiO}_{2}$ content (less than 1\%), which, according to Chayes' criterion (Chayes, 1964), is indicative of a circumoceanic, rather than an oceanic, source region. The Japanese arc has probably contributed substantial amounts of vitric material to these clays as Neogene-Quaternary acid, and intermediate volcanic activity was widespread there (Murakami, 1960; Takai et al., 1962; Oide, 1968). Furthermore, the volcanogenic clays thicken to the west according to the drilling results (Heezen et al., 1973) and seismic reflection profiles (Heezen and Jones, this volume). Site 199 is too far south to be included within the influence of the Japanese arc; this accounts for the contrasting composition of the vitric component of Sample VIII.

During the Late Cretaceous there was extensive acidic and intermediate volcanism in the Japanese arc which, in places, continued into the early Tertiary. Ichikawa et al. (1968) have documented four main stages of activity in southwest Japan during this period. Vast quantities of acidic pyroclastics were produced, particularly during a Gyliakian-early Urakawan episode. These covered a wide area of Japan and would also have been carried far out to sea to contribute to abyssal deposits in the same way as in more recent periods. Basic activity at this time was quite subordinate. However, in the Upper Cretaceous clays at the northern drilling sites, acidic shards are rare and basic glass is abundant. This is an observation which is interpreted here as indicative of a large northward or northwestward movement of the Pacific plate since the Cretaceous. Accepting rates of motion based on the age of the equatorial carbonates in the Leg 20 cores (Heezen et al., 1973), the northern drilling sites would have been some $2000 \mathrm{~km}$ further to the southeast during the Late Cretaceous and thus are well outside the influence of island arc volcanism. The source of the basic glass in these Upper Cretaceous clays is problematic. The small content of acidic glass (Figure 2) suggests a quite local derivation from nearby oceanic volcanoes.

\section{ACKNOWLEDGMENTS}

I thank J.F. W. Bowles, who carried out the microprobe analyses reported here, and M. O'Halloran for preparing the polished mounts. I am grateful to Susan James who was responsible for taking the SEM photographs. Linda Knapp helped to prepare the glass for analysis. I also thank Professor T. Barnard and Neil Fortey for their helpful comments.

\section{REFERENCES}

Brew, D. A. and Muffler, L. J. P., 1965. Upper Triassic glass from Hound Island, Keku Strait, S. E. Alaska: U. S. Geol. Survey Prof. Paper 525C, p. C38. 

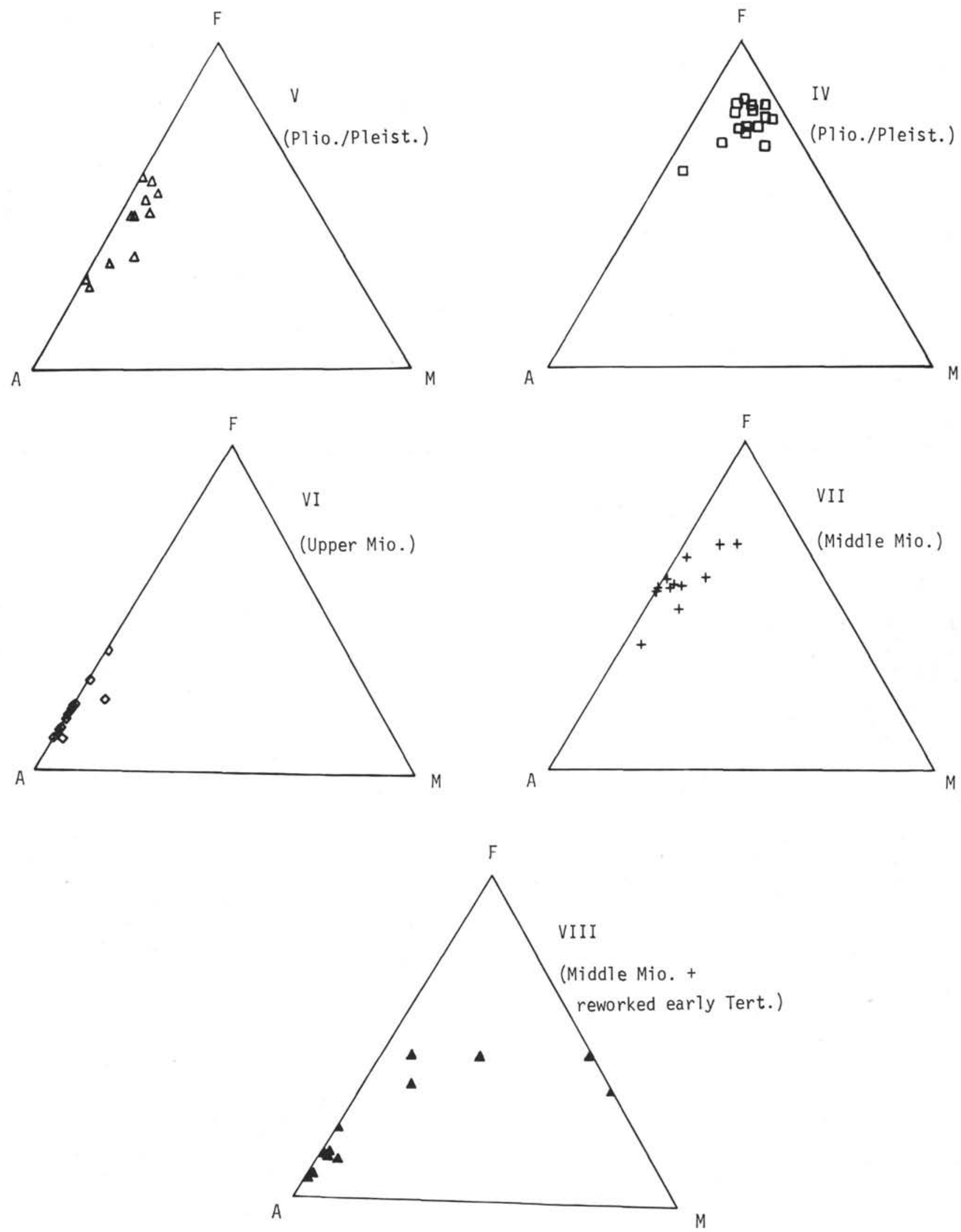

Figure 4. AFM diagrams to illustrate the variation in composition of the glass shards $\left(\mathrm{A}=\mathrm{Na}_{2} \mathrm{O}+\mathrm{K}_{2} \mathrm{O} ; \mathrm{F}=\mathrm{FeO}+\mathrm{MnO}\right.$; $\mathrm{M}=\mathrm{MgO}$ ). (Roman numerals refer to samples in Table 1 and Figure 2.) 


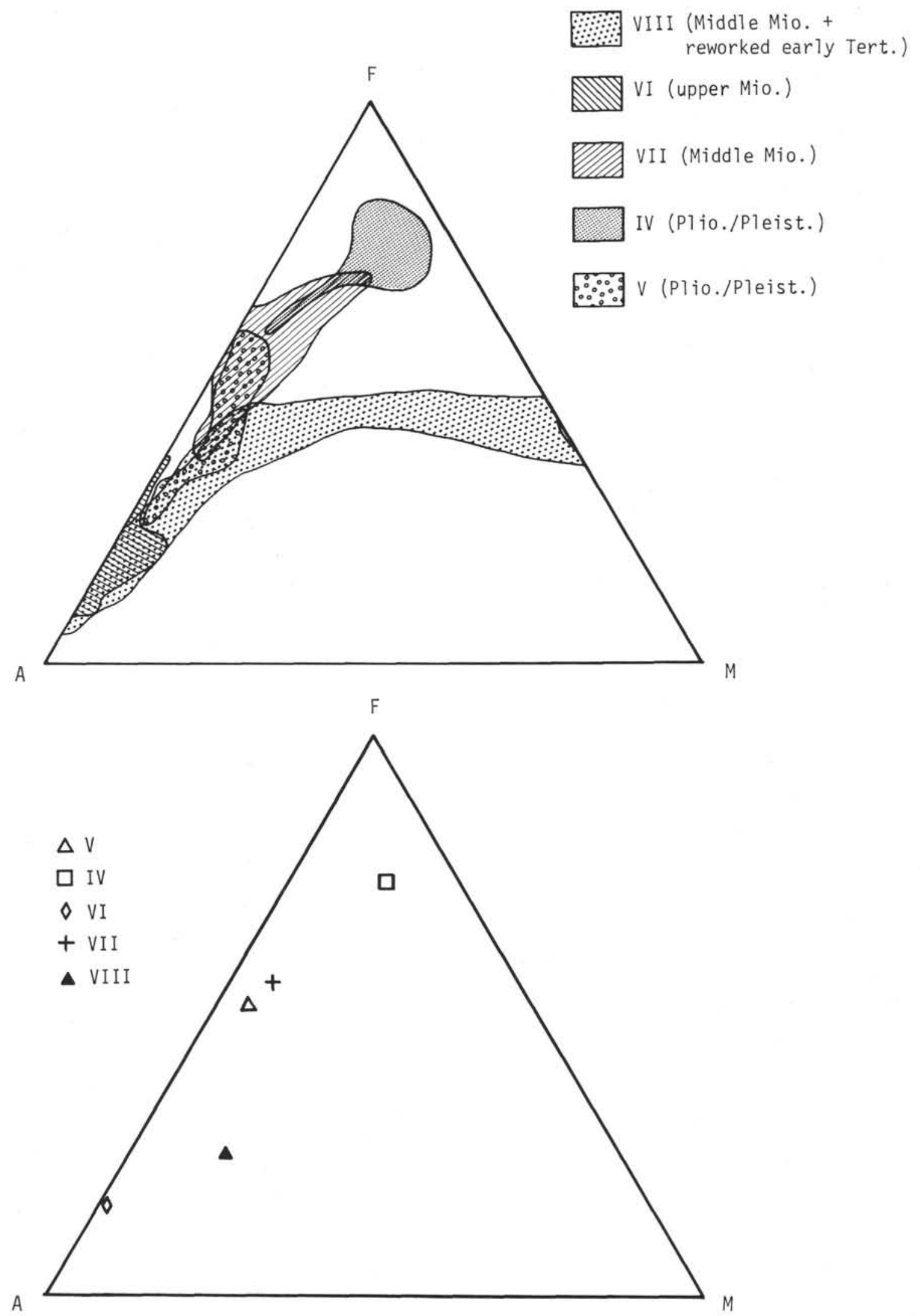

Figure 5. Summary of compositional variation plotted on AFM diagrams. (Roman numerals refer to samples in Table 1 and Figure 1.) 


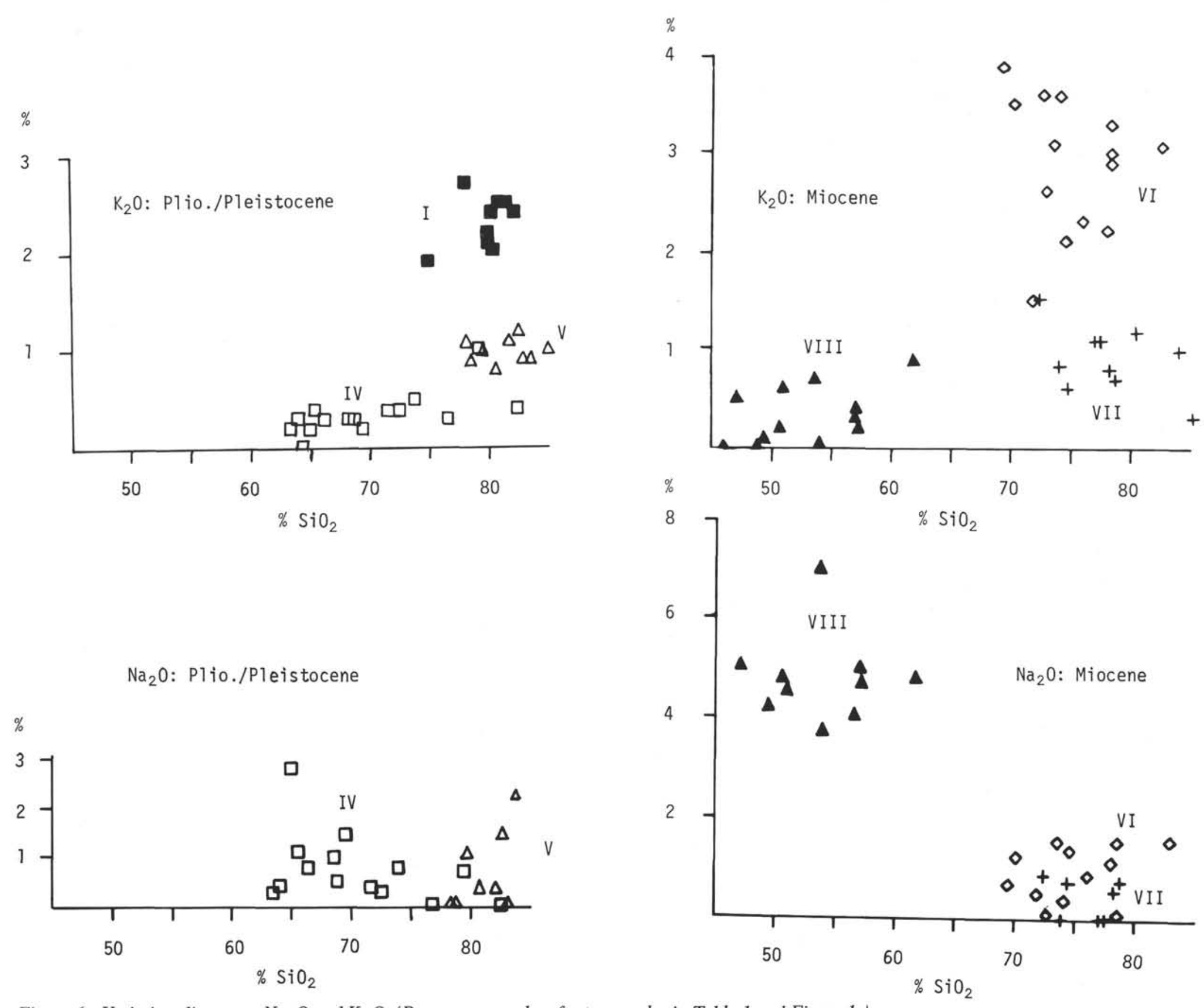

Figure 6. Variation diagrams $-\mathrm{Na}_{2} \mathrm{O}$ and $\mathrm{K}_{2} \mathrm{O}$. (Roman numerals refer to samples in Table 1 and Figure 1.) 

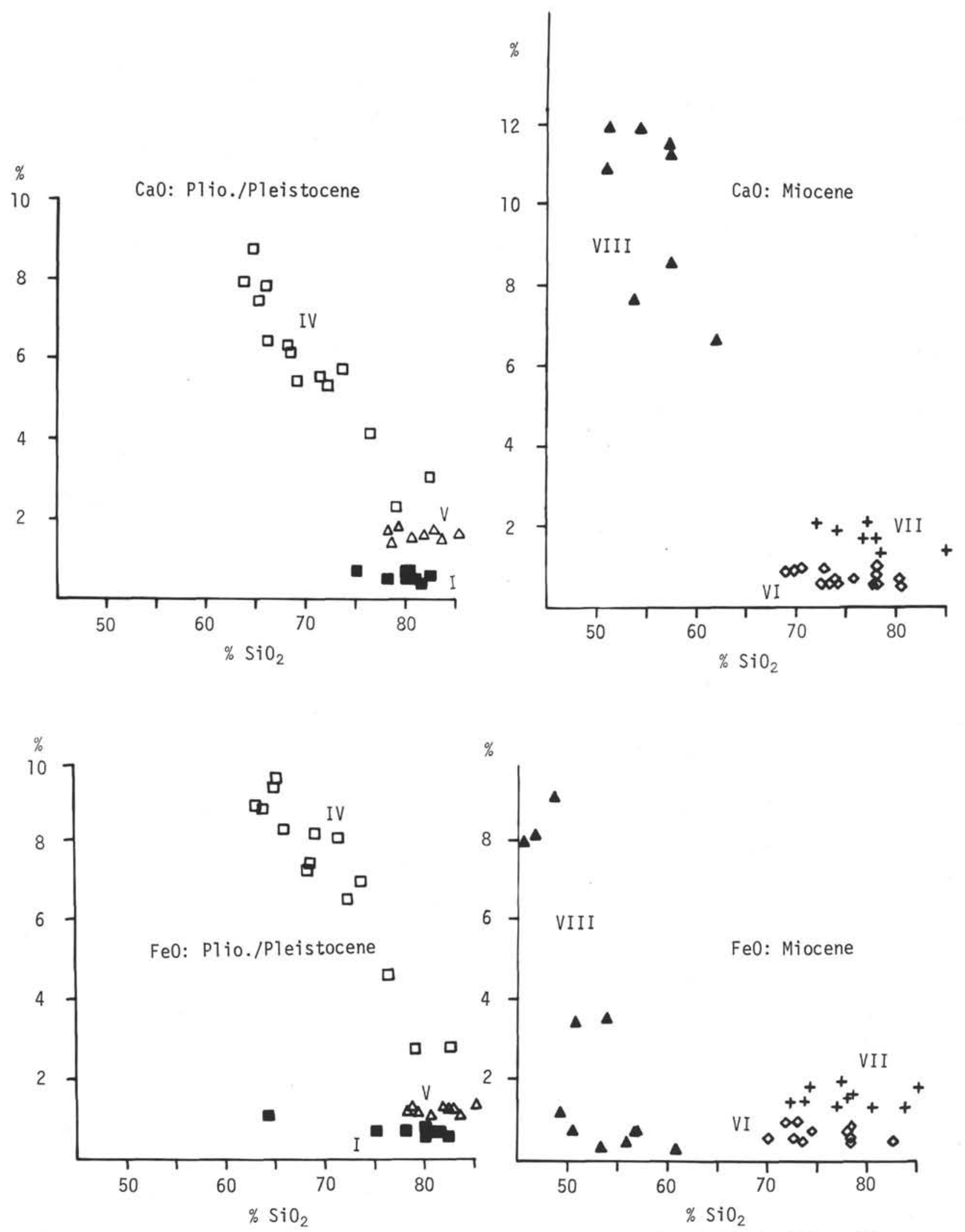

$\%$

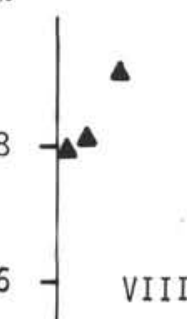

I I

Fe0: Miocene

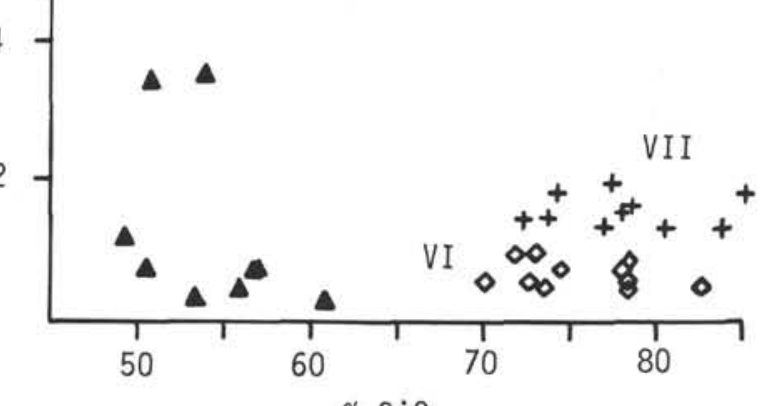

Figure 7. Variation diagram-CaO and $\mathrm{FeO}$. (Roman numerals refer to samples in Table 1 and Figure 1.) 

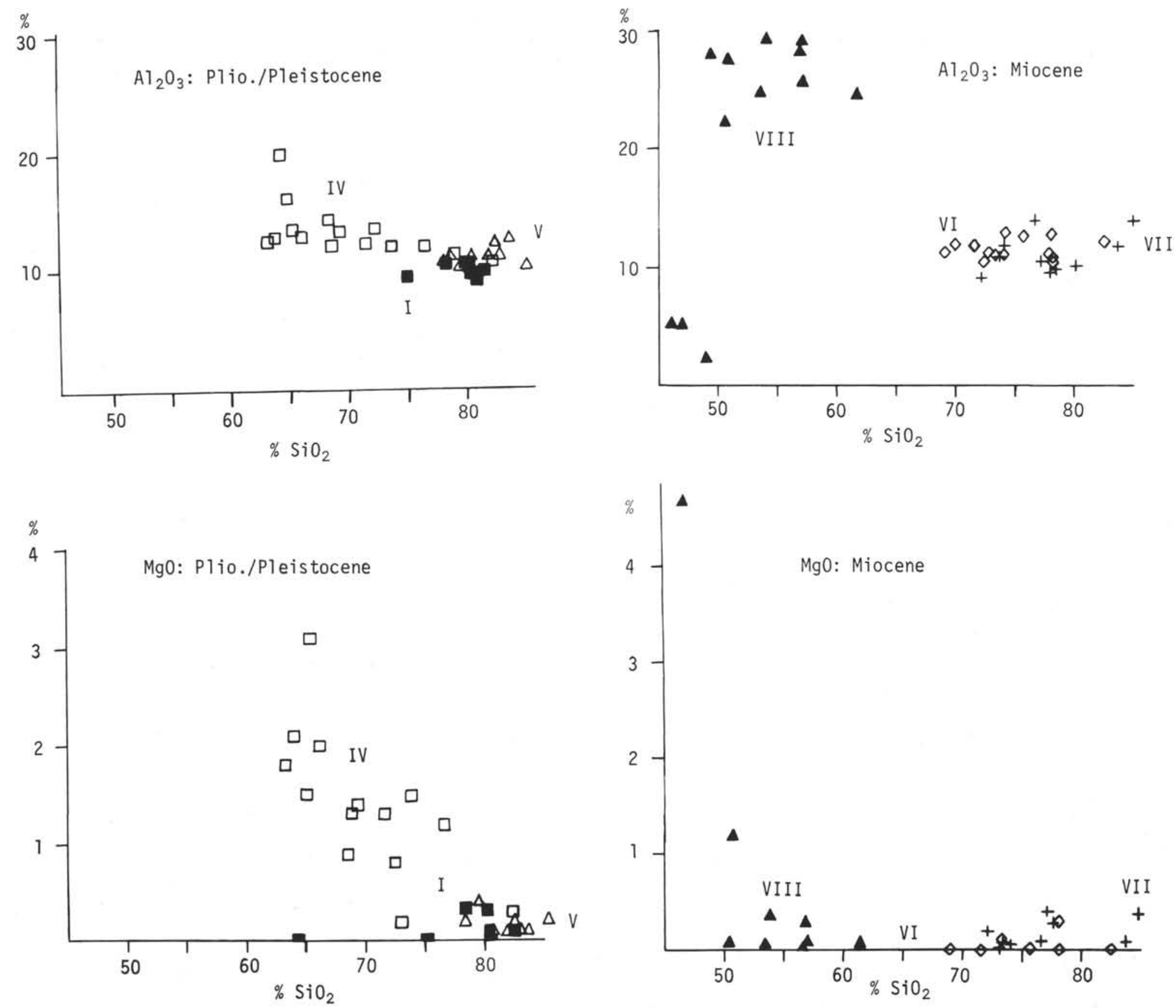

Figure 8. Variation diagram $-\mathrm{Al}_{2} \mathrm{O}_{3}$ and $\mathrm{MgO}$. (Roman numerals refer to samples in Table 1 and Figure 1.) 

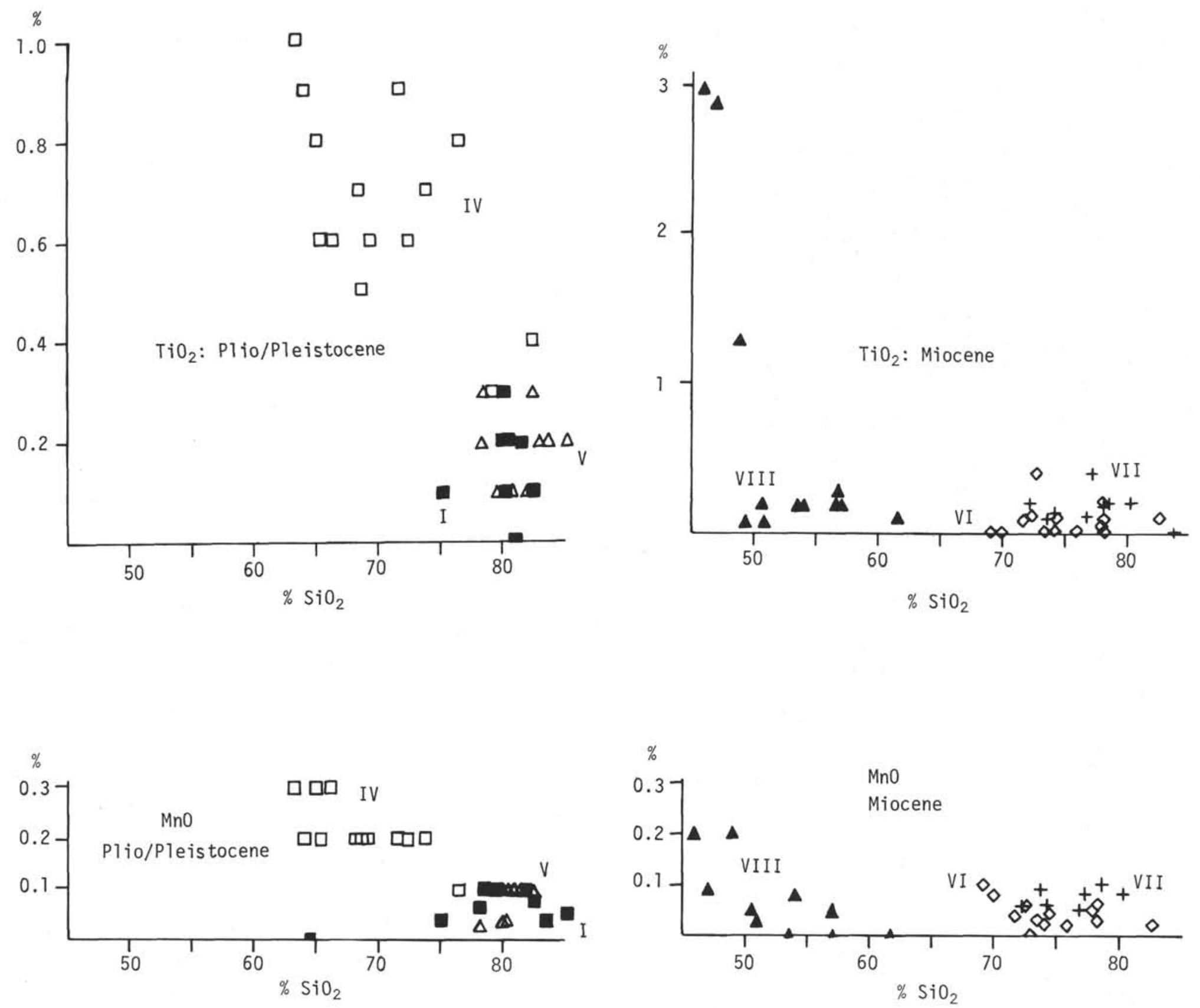


\section{E. J.W. JONES}

Chayes, F., 1964. A petrographic distinction between Cenozoic volcanics in and around the open oceans: J. Geophys. Res., v. 69, p. 1573.

Heezen, B. C., MacGregor, I. D., Foreman, H. P., Forristall, G., Hekel, H., Hesse, R., Hoskins, R. H., Jones, E. J. W., Kaneps, A., Krasheninnikov, V. A., Okada, H., and Ruef, M. H., 1973. Diachronous deposits: a kinematic interpretation of the post-Jurassic sedimentary sequence on the Pacific plate: Nature, v. 241, p. 25.

Heiken, G., 1972. Morphology and petrography of volcanic ashes: Geol. Soc. Am. Bull., v. 83, p. 1961.

Horn, D. R., Delach, M. N., and Horn, B. M., 1969. Distribution of volcanic ash layers and turbidites in the North Pacific: Geol. Soc. Am. Bull., v. 80, p. 1715.

Horn, D. R., Horn, B. M., and Delach, M. N., 1970. Sedimentary provinces of the North Pacific: Geol. Soc. Am. Mem., v. 126, p. 1.

Ichikawa, K., Murakami, N., Hase, A., and Wadatsumi, K., 1968. Late Mesozoic igneous activity in the inner side of southwest Japan: Pacific Geol., v. 1, p. 97.

Mason, P. K., Frost, M. T., and Reed, S. J. B., 1969. Program for calculating corrections in quantitative X-ray microanalysis: IMS Rept. No. 2 .

Moore, J. G., 1970. Water content of basalt erupted on the ocean floor: Contrib. Mineral. Petrol., v. 38, p. 272.

Muffler, L. J. P., Short, J. M., Keith, T. E. C., and Smith, V. C., 1969. Chemistry of fresh and altered basaltic glass from the Upper Triassic Hound Island volcanics, southeastern Alaska: Am. J. Sci., v. 267, p. 196.

Murakami, N., 1960. Cretaceous and Tertiary igneous activity in western Chugoku: Sci. Rept. Yumaguchi Univ. II, v. 21 [In Japanese with English abstract] .

Murray, J. and Renard, A. F., 1891. Report on deep-sea deposits based on the specimens collected during the voyage of H.M.S. Challenger in the years 1872-1876: London (H.M.S.O.).

Ninkovich, D., Opdyke, N. D., Heezen, B. C. and Foster, J. H., 1966. Paleomagnetic stratigraphy, rates of deposition and tephrachronology in the North Pacific deep-sea sediments: Earth Planet. Sci. Lett., v. 1, p. 476.

Oide, K., 1968. Geotectonic conditions for the formation of the Krakatau-type calderas in Japan: Pacific Geol., v. 1, p. 119.

Ross, C. S. and Smith, R. L., 1955. Water and other volatiles in volcanic glass: Am. Mineral., v. 40, p. 1071

Takai, F., Matsumoto, T., and Toriyama, R. (Eds.) (1962): Geology of Japan. Berkeley (University of California Press).

Tilley, C. E., 1922. Density, refractivity and composition relations of some natural glasses: Mineral. Mag., v. 19, p. 275.

Williams, H., Turner, F. J., and Gilbert, C. M., 1954. Petrography: San Francisco (W. H. Freeman and Co.). 



\section{PLATE 1}

Selection of smear slides showing glass fragments

Figure 1 Acidic glass in Quaternary Sample I (194-1-1, 114-115).

Figure 2 Acidic glass in Plio/Pleistocene Sample V (195-1-5, 50-52).

Figure 3 Acidic glass with well-developed pipe vesicles in upper Miocene Sample VII (194-2-1, 145-147).

Figure 4 Acidic glass in middle Miocene Sample VII (195-2-2, 141-143).

Figure 5 Basic glass (center) with inclusions. The matrix is a zeolitic clay. Sample X (196-2-2, 51-53; Campanian).

Figure 6 Basic glass grain (center) with slight alteration on parts of the margin and in small internal cracks (Sample 196-2-2, 61-63; Campanian) 


\section{PLATE 1}

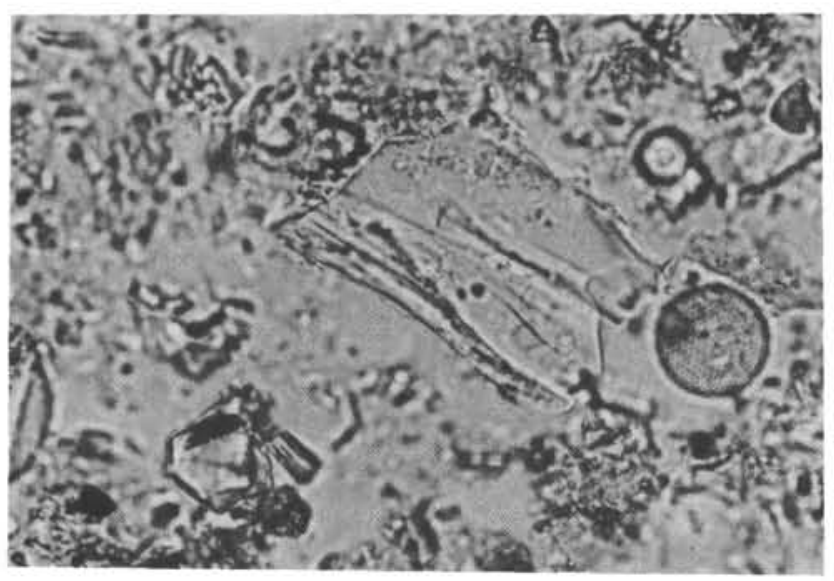

1

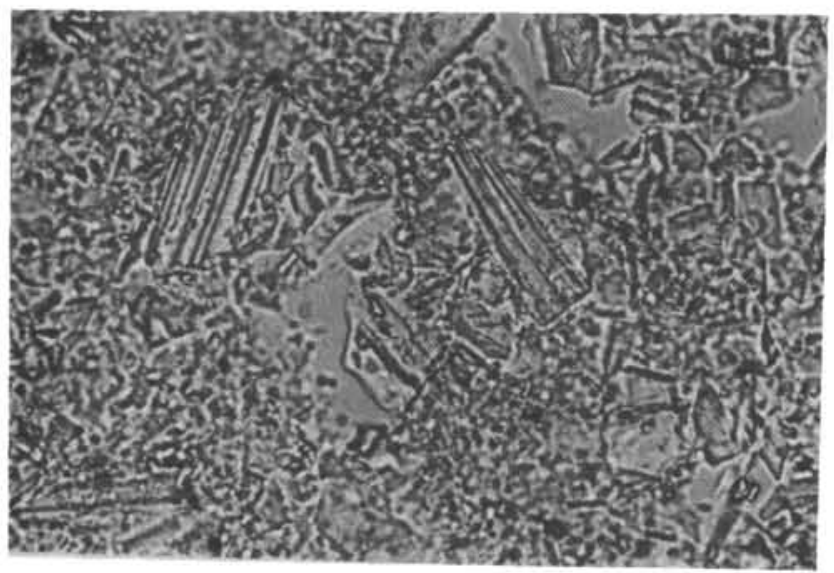

3

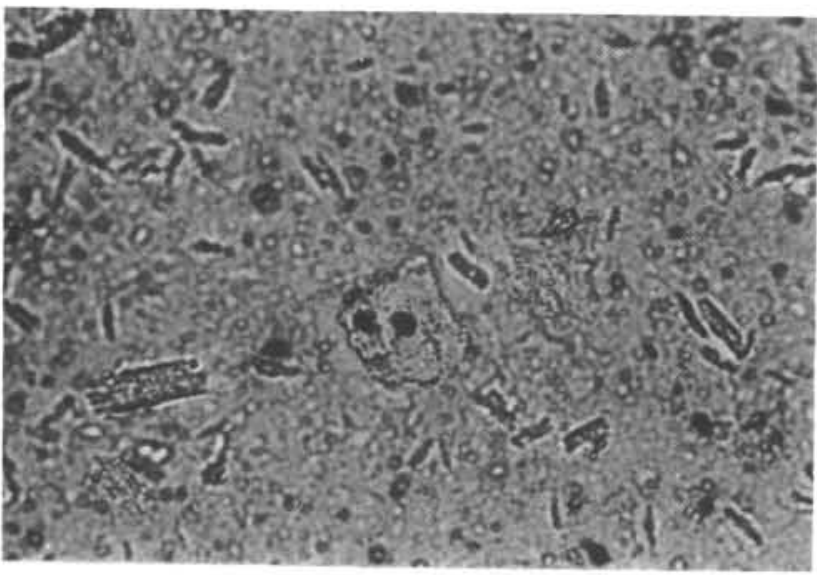

5

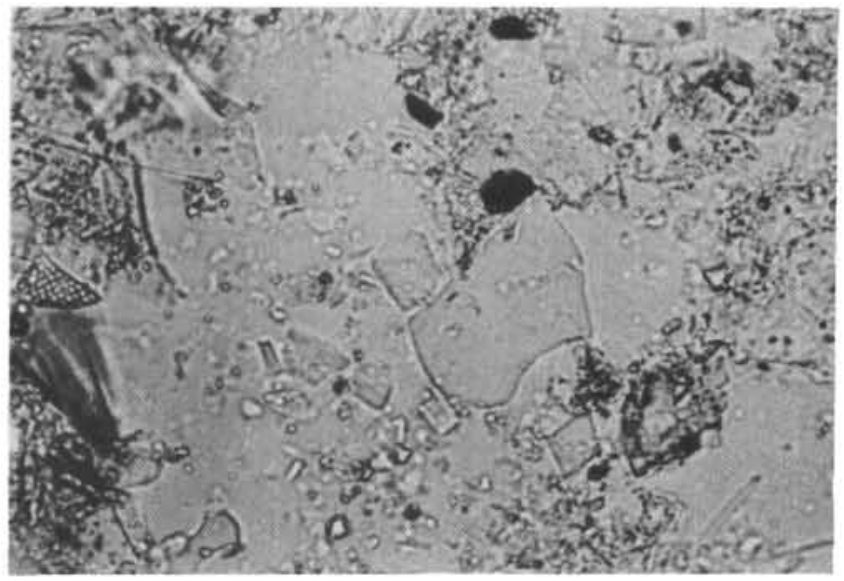

2

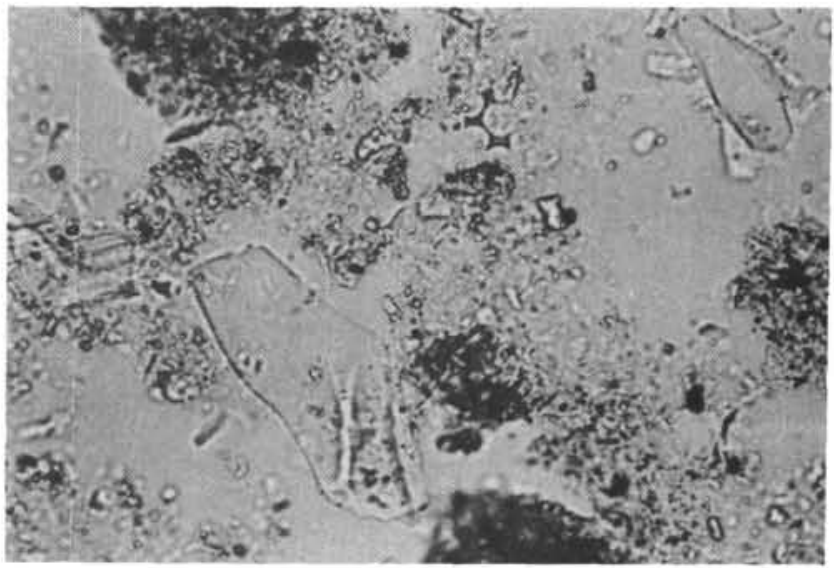

4

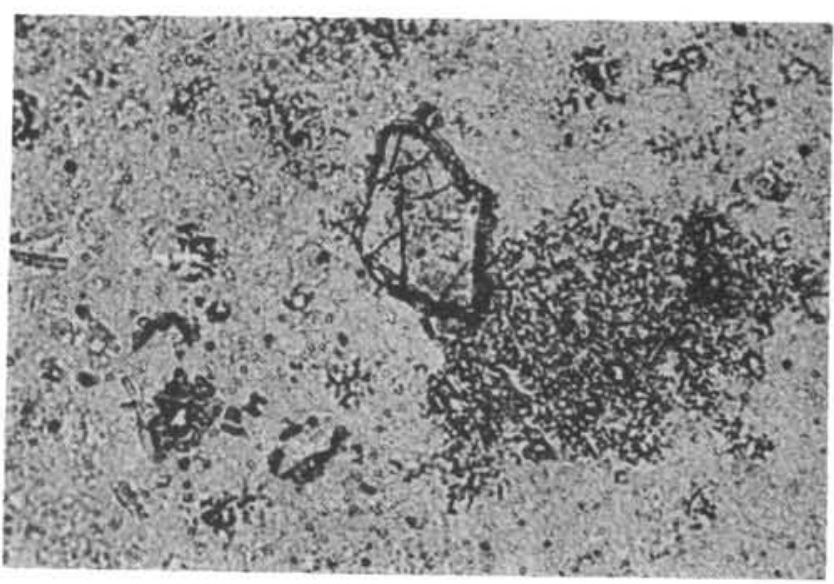

6

$50 \mu$ 
PLATE 2

Glass shards from Sample I (194-1-1, 114-115; Quaternary) on polished mount. 


\section{PLATE 2}

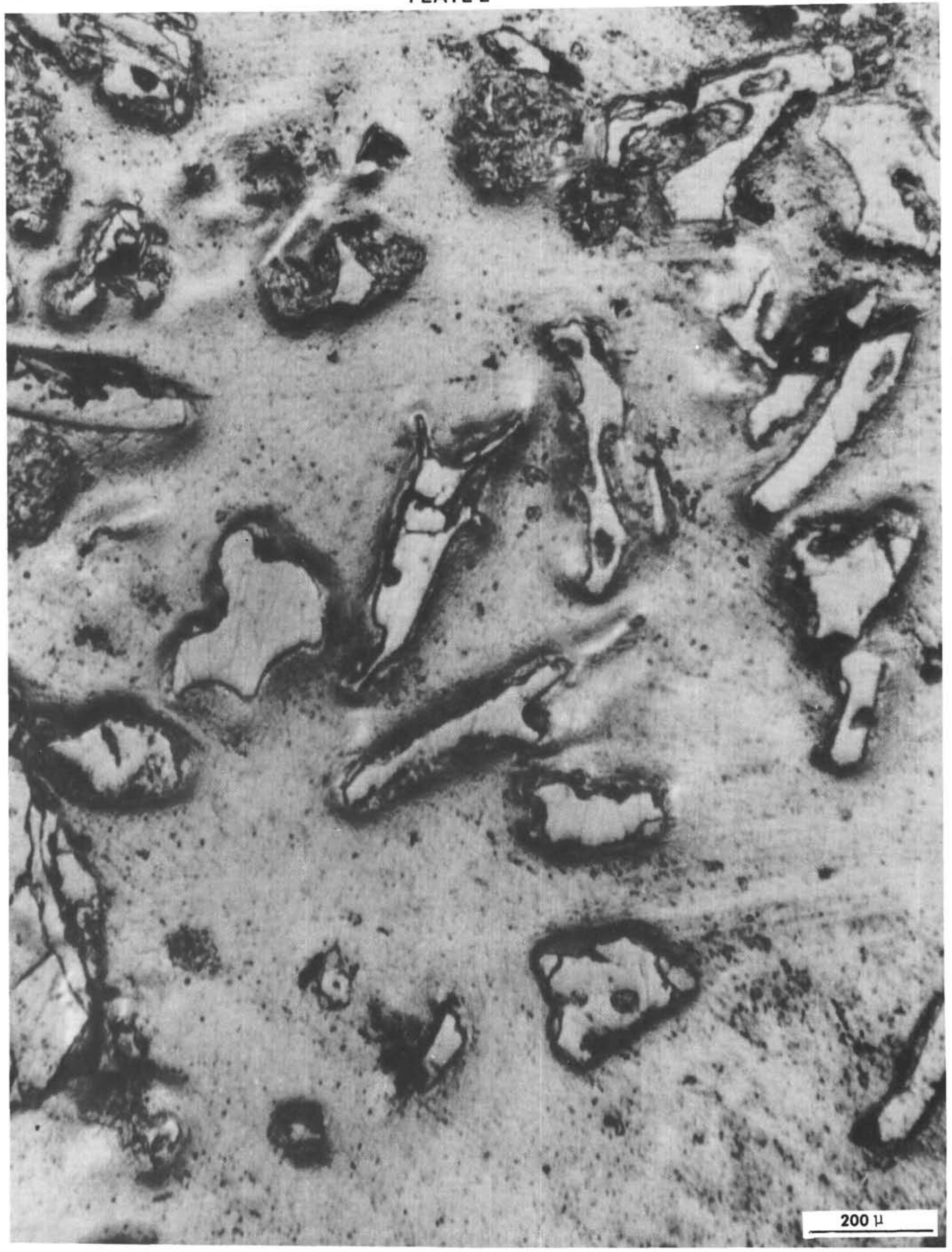


PLATE 3

SEM photographs of glass from Sample I (194-1-1, 114-115; Quaternary). 
PLATE 3

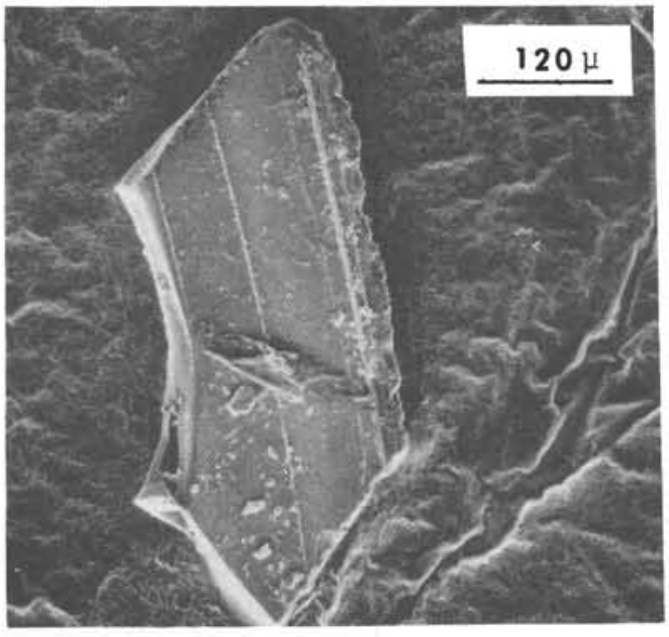

1

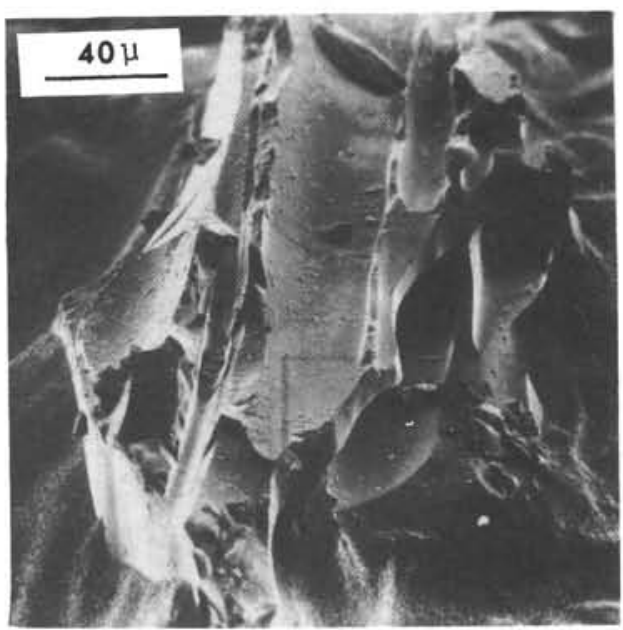

3

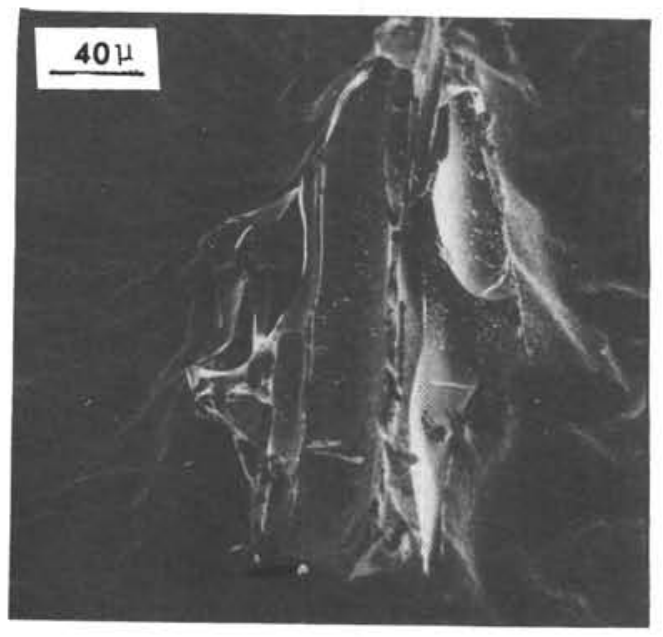

5

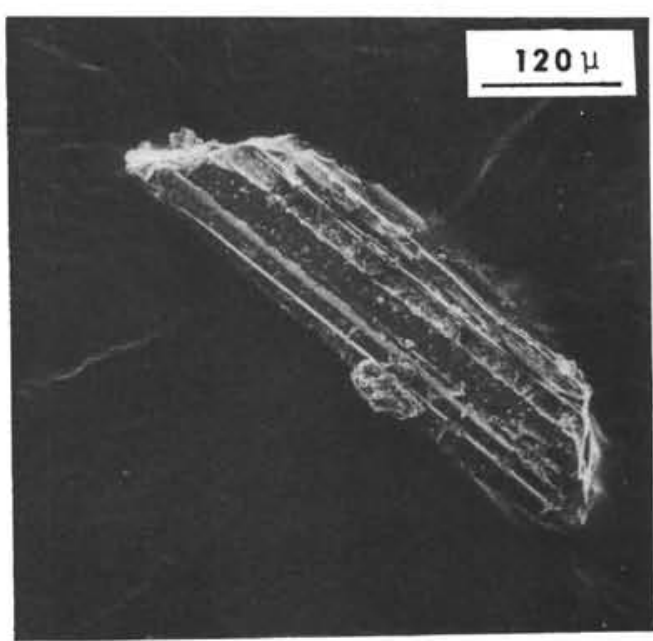

2

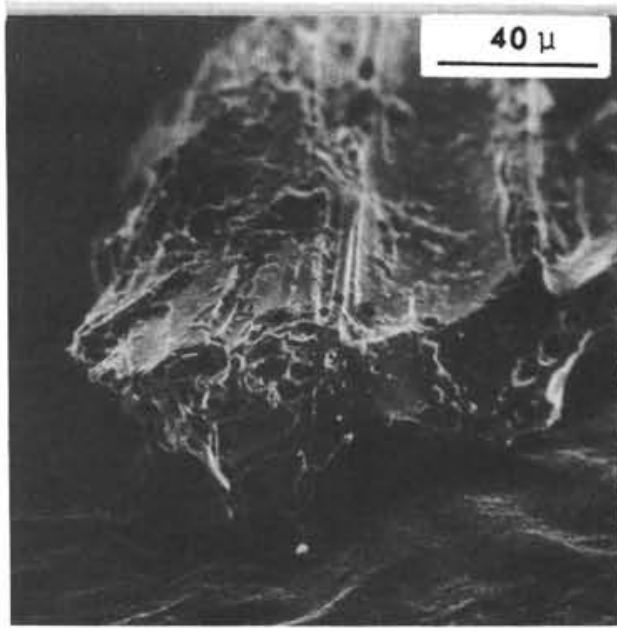

4

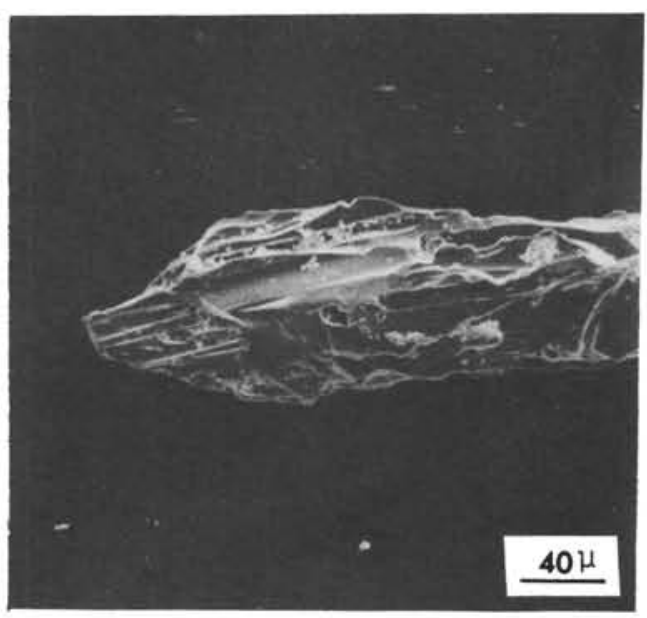

6 
PLATE 4
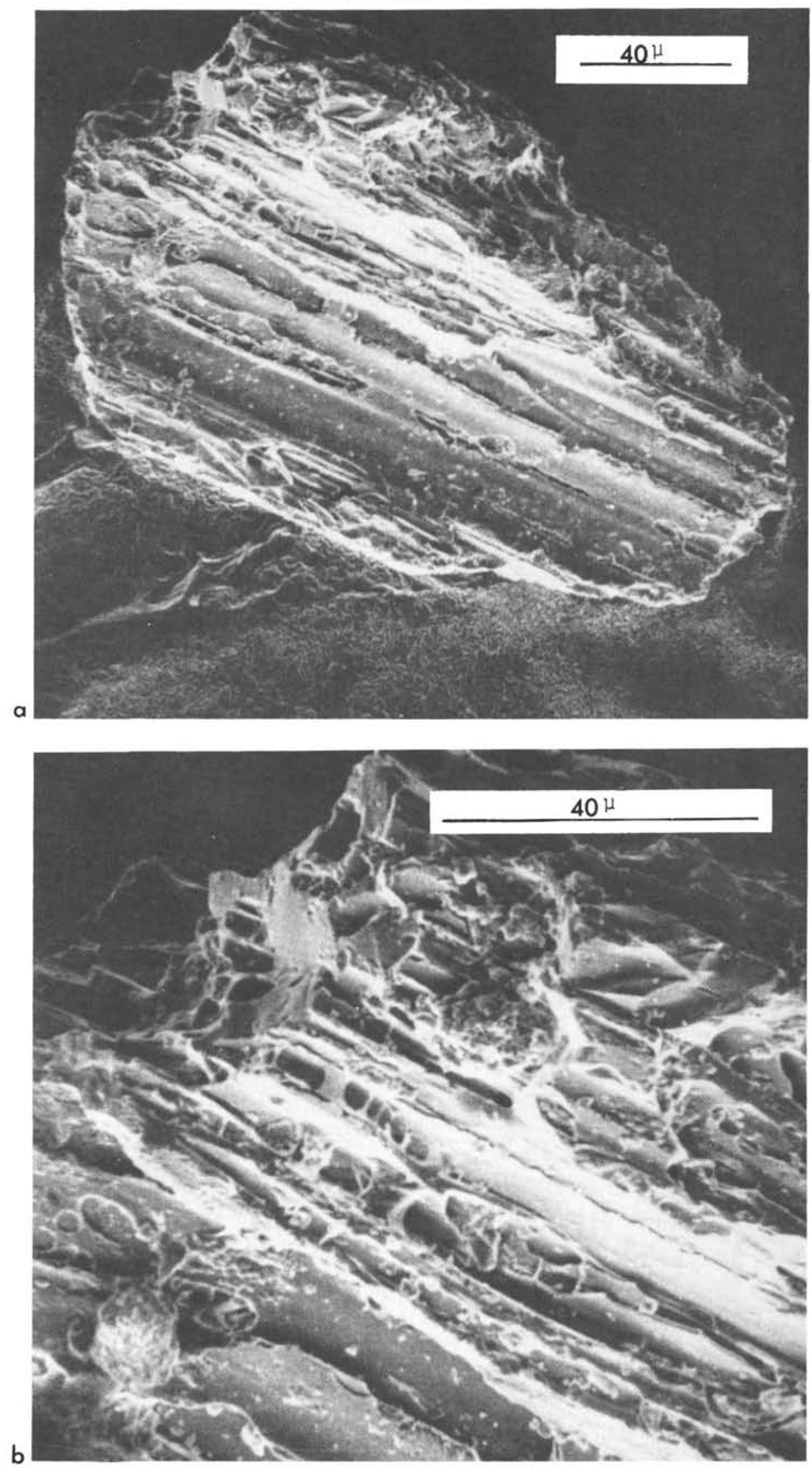

SEM photographs of glass from Sample I (194-1-1; 114-115; Quaternary) exhibiting well-developed pipe vesicles. 


\section{PLATE 5}

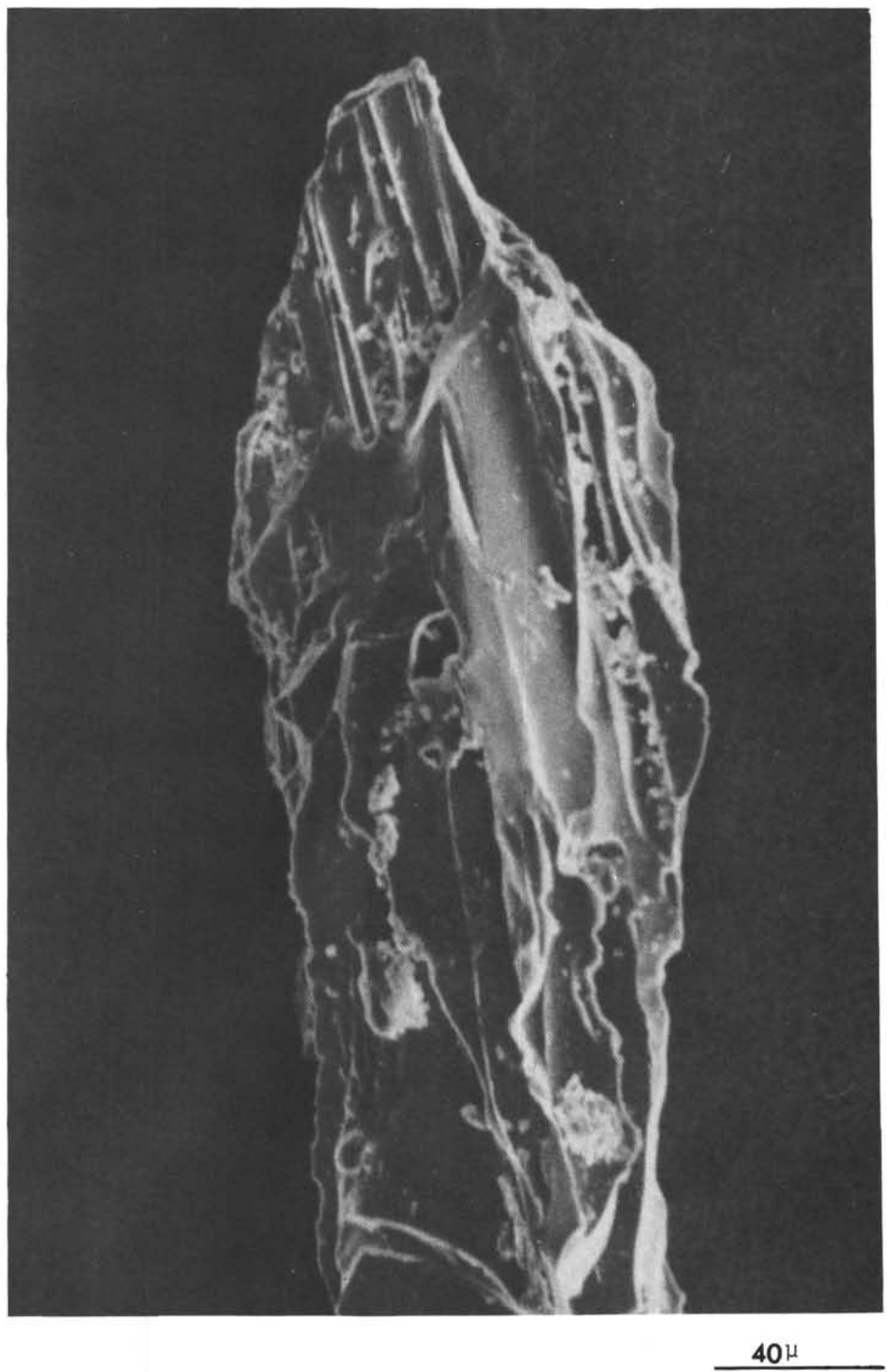

SEM photograph of a shard elongated in the direction of the pipe vesicles. Sample I (194-1-1, 114-115; Quaternary) 
E. J.W. JONES

PLATE 6

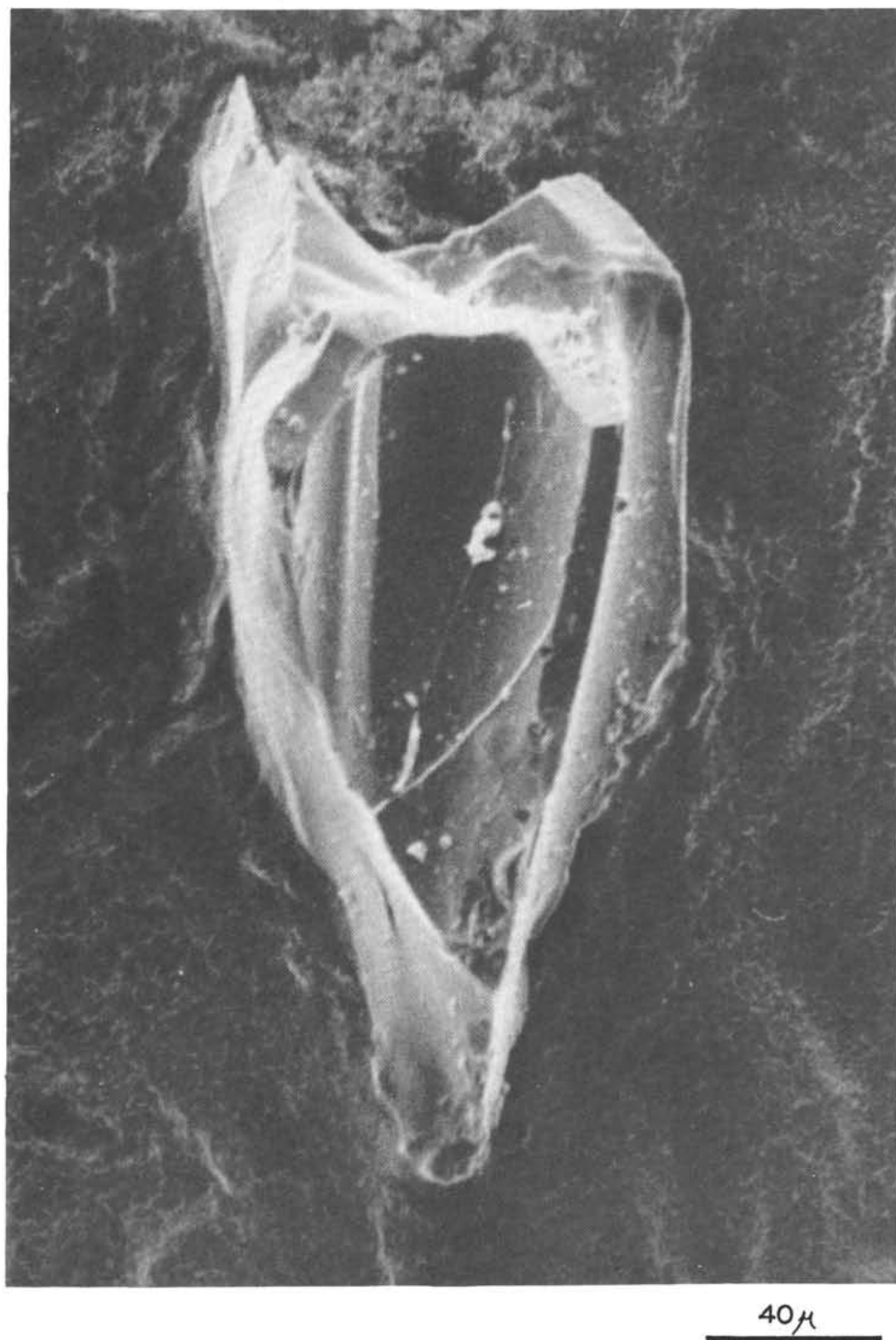

SEM photograph of a glass shard from Sample I (194-1-1, 114-115; Quaternary) 


\section{PLATE 7}

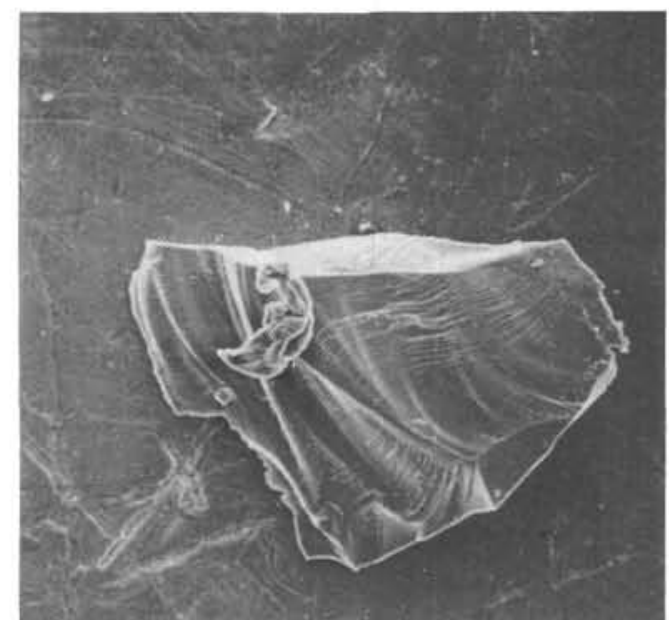

1

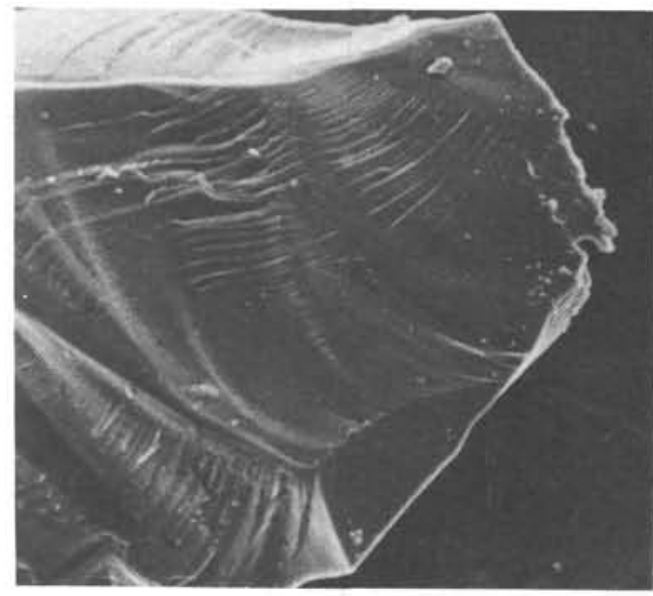

$20 \mu$

3

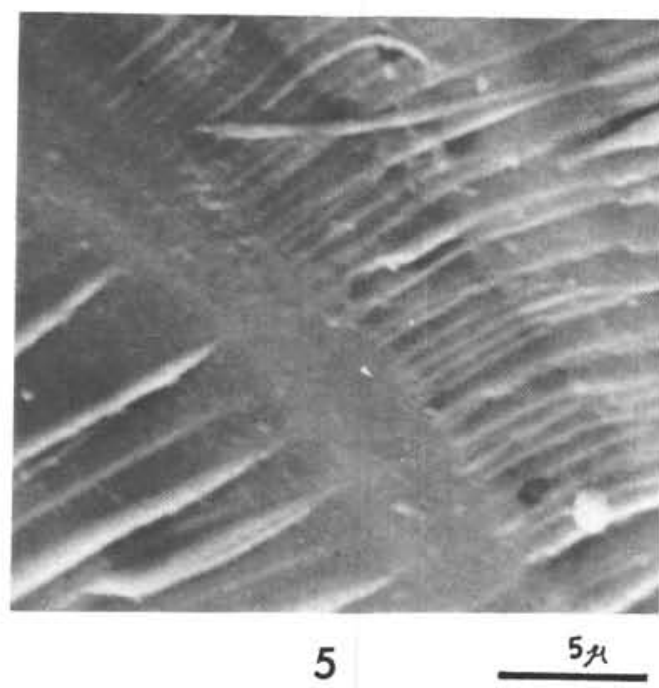

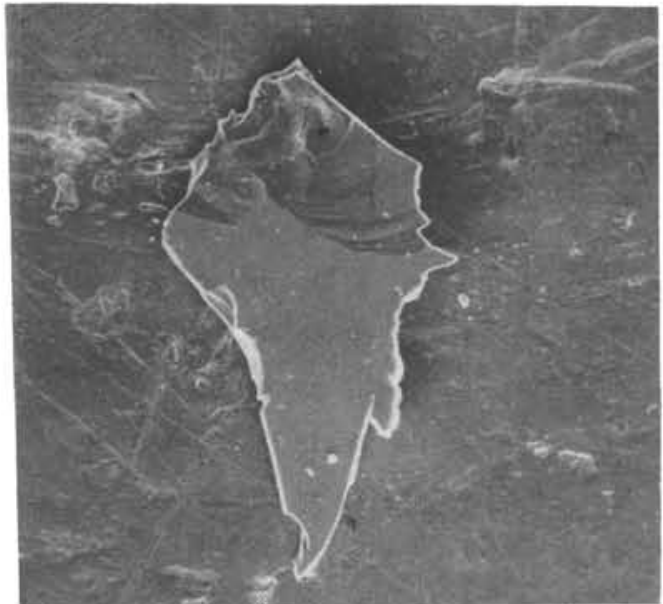

2

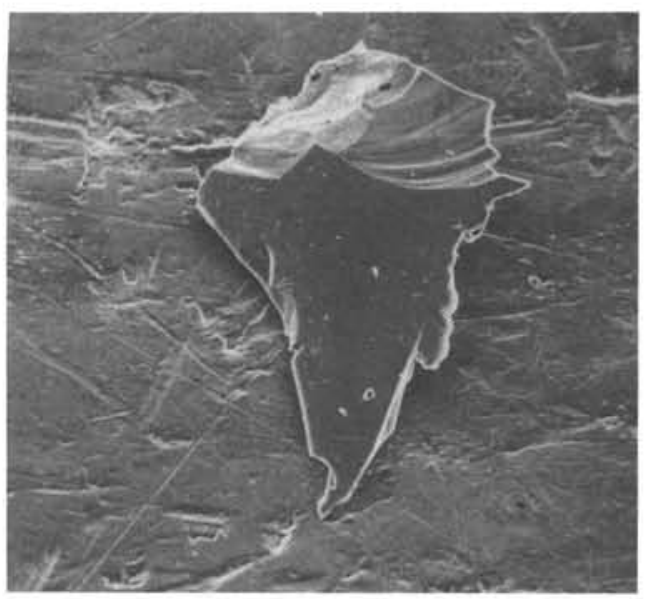

$120 \mu$

4

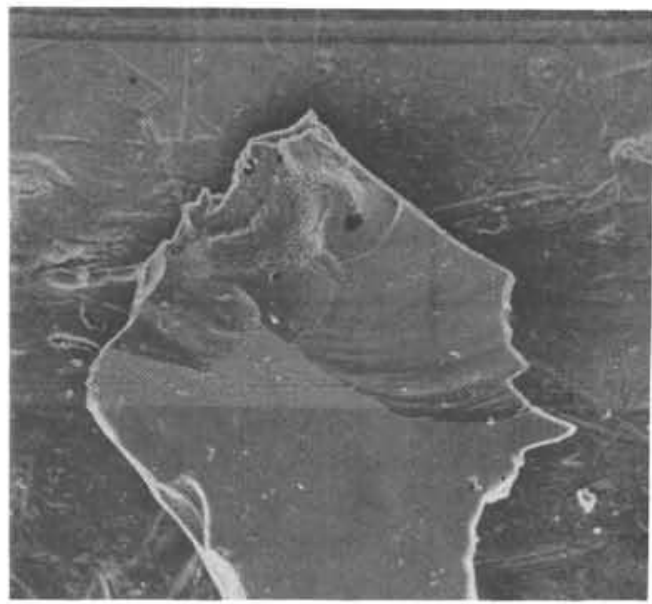

6

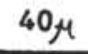

SEM photograph of glass shards from Sample XI (196-2-2; 61-63; Campanian)

Note their marked angularity and the lack of vesicles. The shards show concoidal fracturing and well-developed radian and transverse percussion marks. 
E. J.W. JONES

PLATE 8

SEM photograph of glass fragments from Sample XI (196-2-2; 61-63; Campanian) 


\section{PLATE 8}
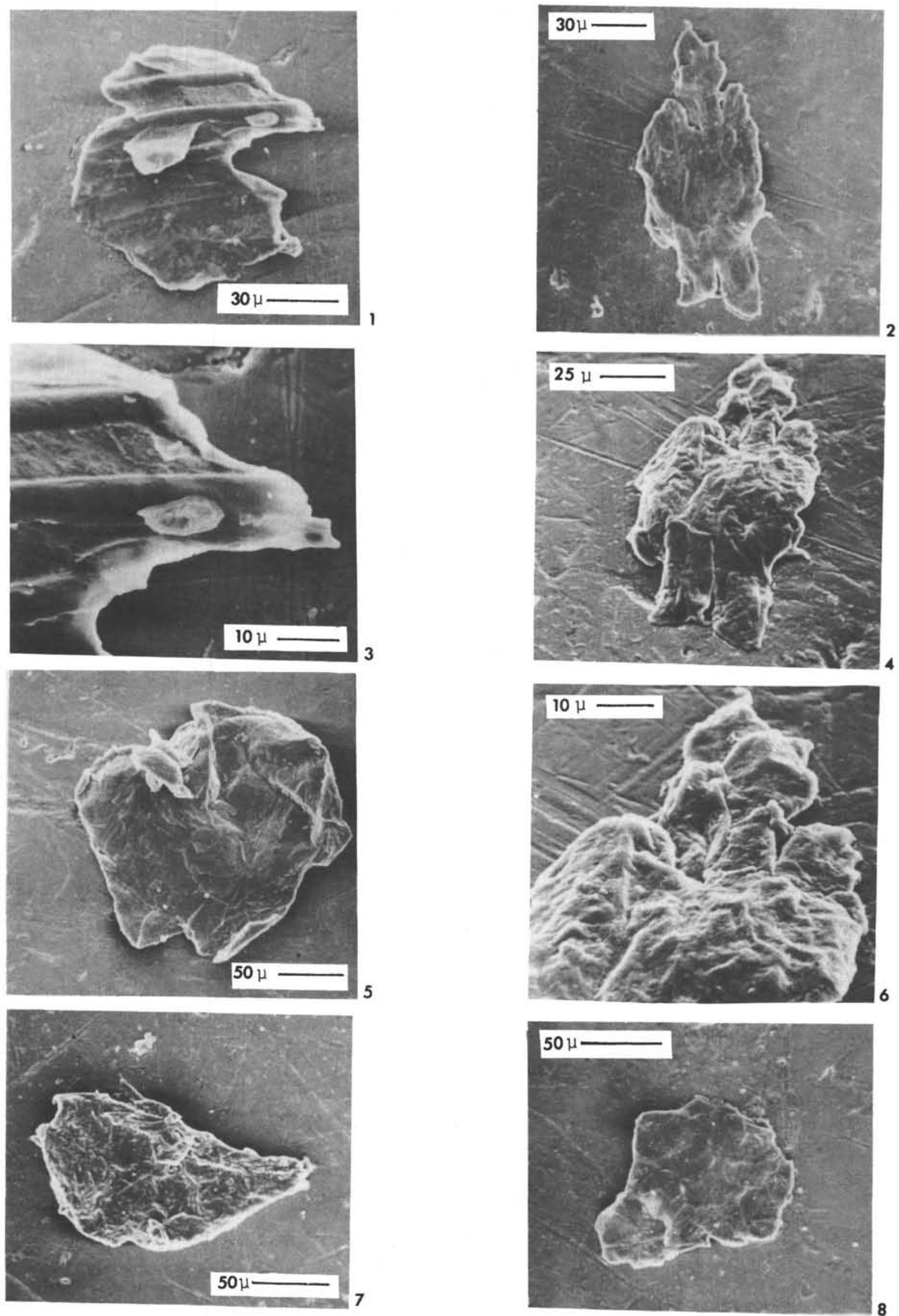


\section{PLATE 9}

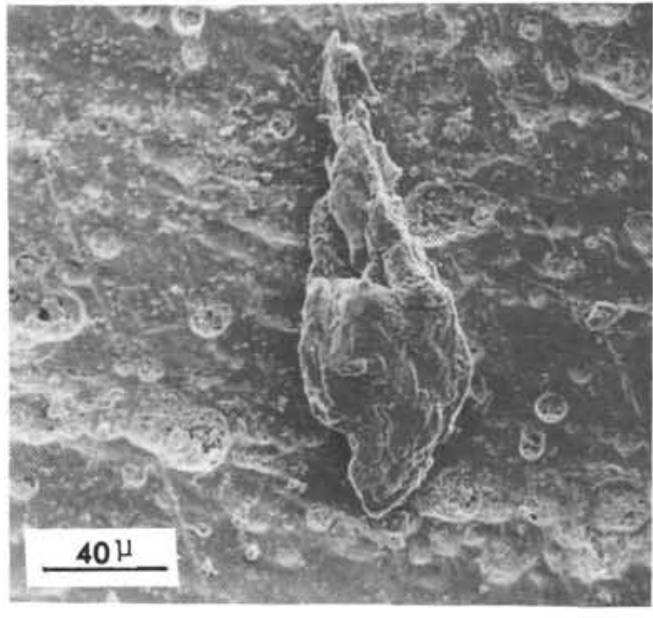

1

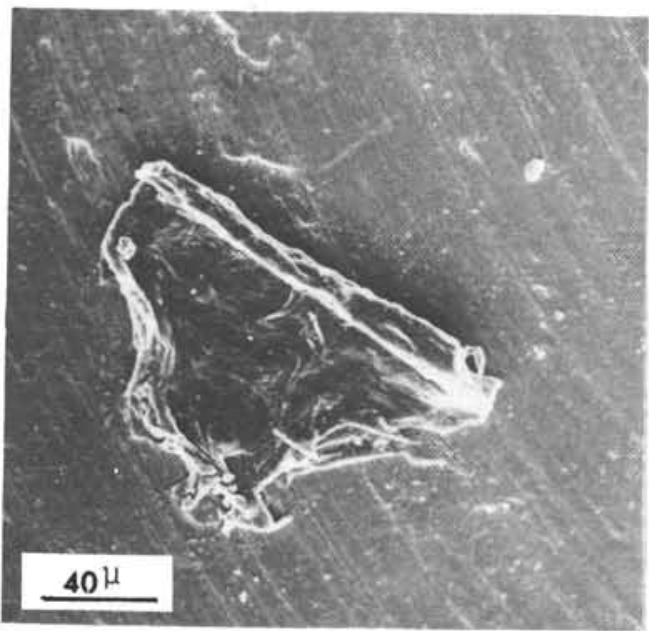

3

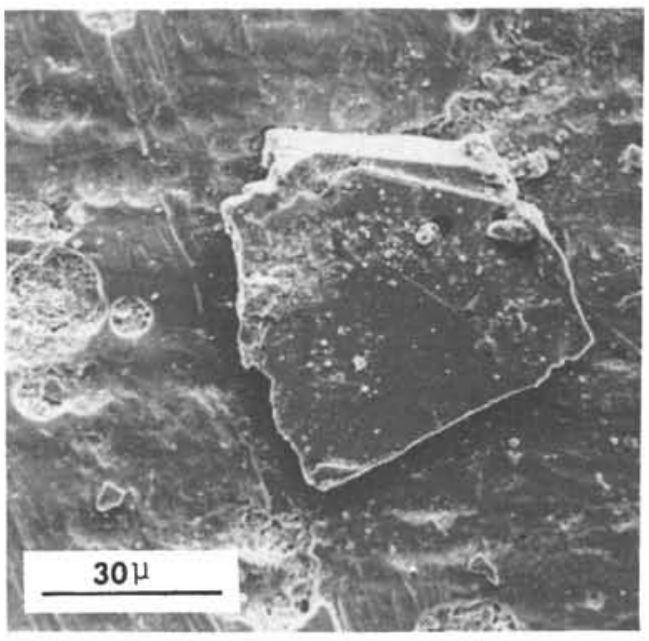

2

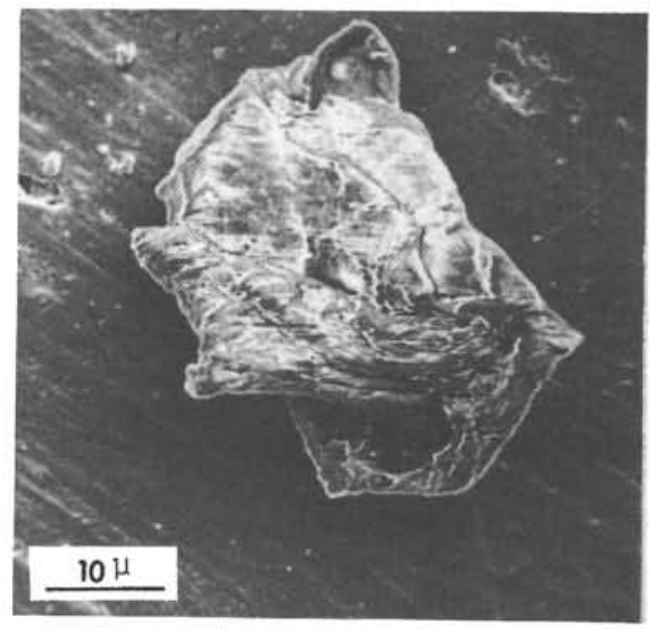

4

SEM photographs of glass from Sample XI (196-2-4, 119-120; Campanian) 